\title{
Producing Blue Elderberry as a Hedgerow- Based Crop in California
}

\section{KATIE FYHRIE, Farmer, \\ formerly with The \\ Cloverleaf Farm in Dixon, California;}

SONJA BRODT, Deputy

Director of the UC

Sustainable Agriculture

Research and Education

Program;

GWENAEL

ENGELSKIRCHEN,

Sustainable Supply

Chain Analyst for the UC

Sustainable Agriculture

Research and Education

Program;

KATIE UHL, Graduate Student Researcher in the Department of Food Science and Technology at UC Davis;

ALYSON MITCHELL,

Professor in the

Department of Food

Science and Technology at UC Davis his guide focuses on producing
California's native blue elderberry

(Sambucus nigra spp. cerulea) in farmedge hedgerows. California growers who plant blue elderberry can benefit from both the marketability and the ecological benefits of elderberry.

As a California native species, blue elderberry supports a diversity of native pollinators and wildlife and contributes to the conservation of native plant communities. Blue elderberry is fast growing and well adapted to many parts of California-from coastal regions to interior valleys and up to approximately 10,000 feet in elevation (fig. 1A) - and provides opportunities for climate-smart farming. But blue elderberry also qualifies as a unique and distinctive local product with a long history of use by California's Native tribes (fig. 1B).

Market demand for products made from the European and American subspecies of elderberry is rapidly increasing nationwide. Blue elderberry is similar in many ways to these more established commercial subspecies; all three species, for example, contain health-promoting phenolic compounds. The flowers and ripe berries of blue elderberry are safe to eat if properly processed because processing eliminates harmful cyanide-producing glycosides, which are contained in all parts of elderberry plants.

This guide covers growing, harvesting, and marketing of blue elderberry in California, and is based on information from preliminary field trials; from growers, processors, and buyers; and from published conservation research.

\section{The benefits of hedgerows for California's agricultural landscapes}

Blue elderberry is native to California and other western states and is often a component of hedgerows-some planted, some relics of land-clearing - that are found throughout California's farmland, especially in the Central Valley and in coastal agricultural regions. Hedgerows are typically defined as managed rows of trees and shrubs that can also include perennial or annual forbs and grasses (Baudry et al. 2000; Earnshaw 2018). Hedgerows are an ancient feature of agricultural landscapes around the world. They have been used to delineate field boundaries, fence in and shelter livestock, and provide windbreaks to protect crops and buildings. Historically, they have often also provided supplemental foods such as berries, nuts, and wild game.

During the 1900s, farmland in industrializing regions of Europe and the United States experienced waves of hedgerow removal, but today the ecological value of hedgerows is increasingly recognized. Hedgerows add critical elements of natural biodiversity to intensively farmed and often highly simplified agricultural landscapes.

Compared to bare or weedy field margins, mixed-species hedgerows composed primarily of California native species support significantly higher populations of common and rare bird species (Heath et al. 2017). They also support substantially higher numbers of natural enemies of common crop pests. Studies have demonstrated that these natural enemies move up to 600 feet into adjacent crop fields, resulting in a reduction in the total number of pesticide applications required over the 
(A)

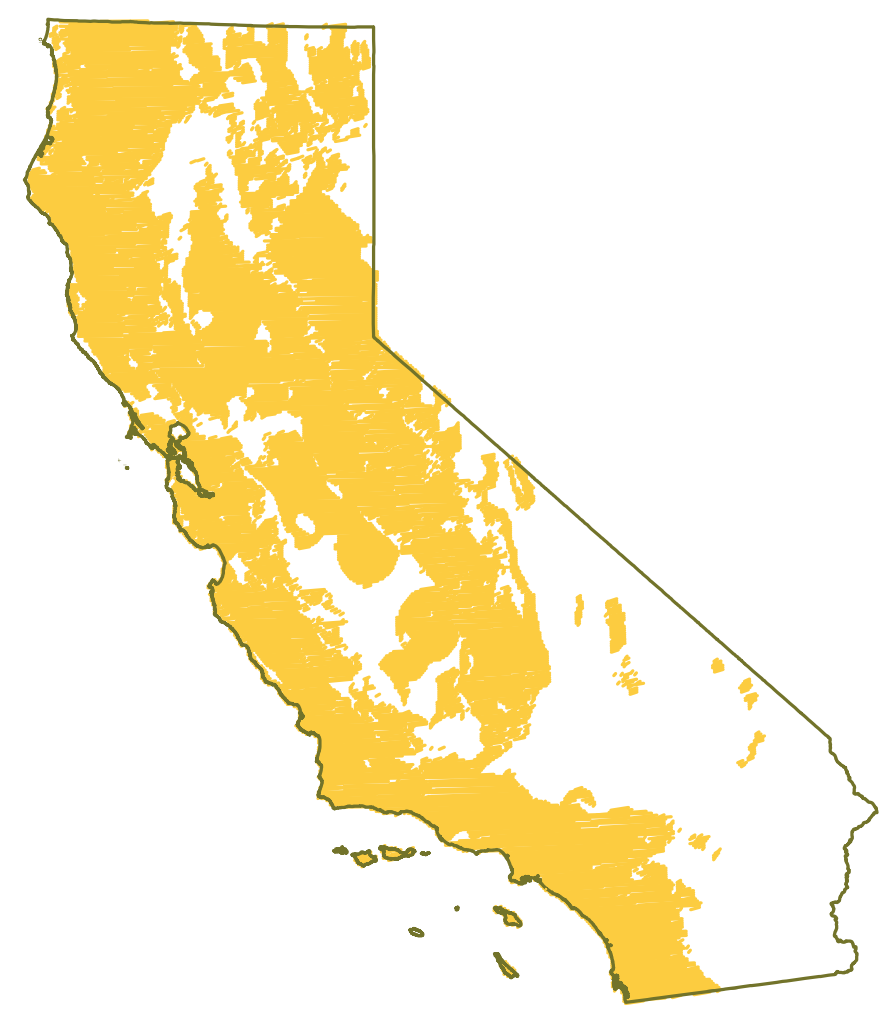

(B)

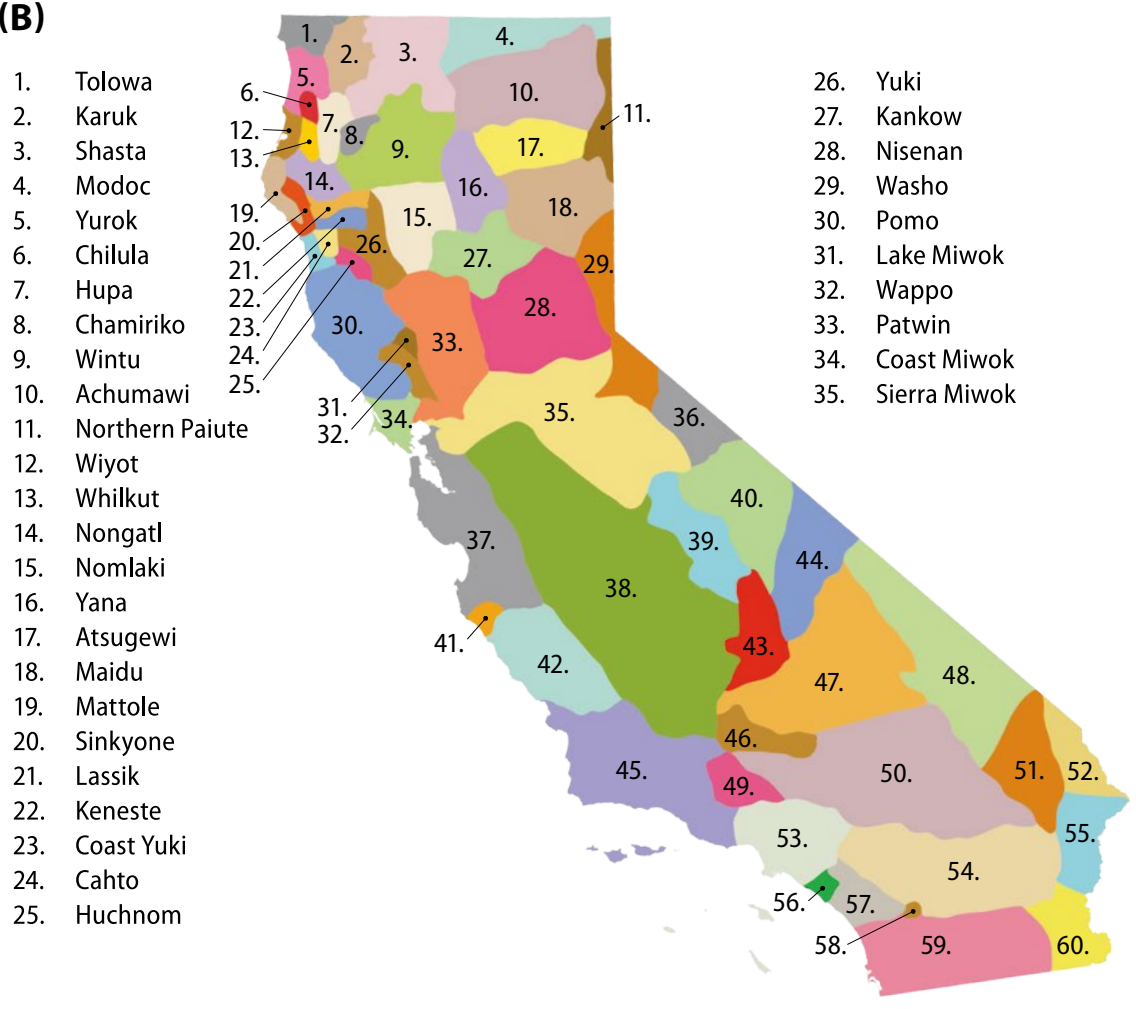

36. Numa

37. Ohlone

38. Yokut

39. Mono

40. Nuumu

41. Esselen

42. T'epotaha'l

43. Tubatulabal

44. Western Shoshone

45. Chumash

46. Kitanemuk

47. Kawaiisu

48. Southern Paiute

49. Tataviam

50. Maarenga'yam

51. Chemehuevi

52. Mojave

53. Tongva

54. Iviatim

55. Hakhidhoma

56. Acjachemen

57. Payómkawichum

58. Kuupangaxwichem

59. Kumeyaay

60. Quechan

Figure 1. The estimated distribution range of blue elderberry (A) lies within the traditional homelands of many California Native tribes (B). 
growing season. This reduction in applications reduces total pest-control costs compared to fields with typical weedy edges (Morandin et al. 2014, 2016). Populations of native pollinators and honey bees are also noticeably increased in fields next to hedgerows and wildflower strips (Morandin and Kremen 2013; Williams et al. 2015). Finally, maintaining perennial hedgerows is an excellent means of achieving long-term carbon storage in agricultural landscapes. One study in Yolo County found that hedgerows on annual crop farms stored 18 percent of the total carbon on a farm while occupying only 6 percent of the land area (Smukler et al. 2010). Establishing perennial hedgerows is a practice supported by two incentive programs-California's Healthy Soils Program, which aims to improve carbon sequestration and reduce greenhouse gas emissions in California's working landscapes, and the Environmental Quality Incentives Program of the U.S. Department of Agriculture's Natural Resources Conservation Service.

Elderberry can be a valuable component of hedgerows. It is relatively easy to establish and quickly gains in size during the first few years. Its canopy provides cooling shade, especially useful for streams, and its roots stabilize soil and stream banks. Game birds and other types of wildlife, including deer, bears, and elk, feed on its foliage and fruit in the summer. Elderberry is a key summer food source for many species of native songbirds, which also use elderberry as nesting habitat. Elderberry also hosts moths and butterflies and attracts a range of native pollinators and predatory wasps. Elderberry is the sole host for the threatened valley elderberry longhorn beetle, a species that appears only in the Central Valley of California (beginning on p. 19, see the section on the Endangered Species Act and programmatic safe harbor agreements).

\section{Elderberry's cultural and traditional medicinal significance}

Indigenous peoples were the first harvesters and tenders of blue elderberry in California. Many Native people across the state continue to gather, cultivate, and use elderberry (see fig. 1B). Various parts of the plant are used for food, medicine, pipes, game pieces, musical instruments such as flutes and ceremonial clapper sticks, and dye color for baskets. Since precontact times, elder flowers have been used medicinally-in teas for treating fevers and other ailments, or in hot baths to induce sweating (Timbrook 1990; Lightfoot 2009; Walker 2004) — and elderberries are dried to store for the winter, when they can be cooked into a rich, sweet sauce (Barrows 1900; Barret 1933; Lightfoot 2009).

"Elderberry is one of our most important traditional medicines and we've never stopped using it," says Sage LaPena, a Nomtipom and Tunai Wintu ethnobotanist and certified medical herbalist (UC ANR 2021). "When we look at our traditional ecological knowledge, how we use elderberry-which includes all of the parts of the plant: roots, wood, berry, flowerthey are all harvested at specific times of year."

For some tribes, elderberry's life cycle serves as an indicator of seasonal rhythms, guiding the timing of other food harvests. For the Northern Foothill Yokuts, the elderberry harvest in August coincided with the harvest of sugar pine nuts, and the Coastal Pomo tracked their shellfish gathering window by the flowering and ripening of elderberry (Anderson 2005; Lightfoot 2009).

Prior to Euro-American policies of fire suppression, Native people actively managed elderberry stands, using fire as a strategy to reduce plant density, increase fruit production, and encourage the growth of long, straight shoots usable for musical instruments (Anderson 2005; UC ANR 2021). Today, although native blue elderberry grows readily from the foothills to the coast, Native people face barriers to attaining abundant elderberry supply because of the loss of land access, loss of harvesting rights, vegetation removal for land development, and federal endangered-species regulations. Higher interest in elderberry has also led to increased wild-foraging by non-Native wild crafters, which risks further reduction of availability for Native people and increases the importance of planting elderberry on cultivated land. 


\section{Elderberry subspecies}

Three subspecies of elderberry (Sambucus nigra L.) produce edible flowers and berries-Sambucus nigra ssp. nigra (European elderberry), Sambucus nigra ssp. canadensis (American elderberry), and Sambucus nigra ssp. cerulea (blue elderberry) (Stevens 2001). (Sambucus racemosa var. melanocarpa, or red elderberry, is toxic; see sidebar 1, beginning on this page). All three subspecies that produce edible flowers and berries are large, winter-deciduous, multistemmed shrubs or small trees. White or cream-colored flowers emerge in spring and summer and are borne in large, flat cymes. Prolific clusters of many small berries-dark purple or blue-black-ripen in the summer. The flavor of flowers and berries varies among the three subspecies; as a result, they may not be interchangeable from a marketing perspective.

\section{American and European elderberry}

At this writing, commercial elderberry production in the United States is most prevalent in the Midwest. Production in that region focuses primarily on American elderberry, which is native to a broad range of North America east of the Rocky Mountains. The extent of commercial cultivation of European elderberry cultivars in the United States is thought to be small, but data are lacking.

\section{SIDEBAR 1}

\section{Red elderberry}

Those who wild-harvest or propagate from local wild plants in California should take care to avoid the toxic red elderberry (Sambucus racemosa var. melanocarpa). A California native, red elderberry is found in northern coastal regions and in the Sierra Nevada. The most reliable way to distinguish red elderberry from blue elderberry is by the color of the ripe berries. As its name suggests, red elderberry's fruit is bright red when ripe. Flowers can also be used to distinguish the two species: Red elderberry flowers are borne in cone-shaped clusters, in contrast to the blue elderberry's large, flat cymes (CNPS 2021c) (sidebar 1 fig. 1).
Cultivars of both American and European elderberry have been bred for desirable characteristics in the regions where they are most prevalently grown. Cuttings and potted plants of these cultivars are available for purchase from producers and nurseries in the United States-but their performance under California growing conditions has not been comprehensively evaluated. While some growers in Central Coast counties have experienced success with American elderberry cultivars on a small scale, a preliminary 2.5-year demonstration trial in the Sacramento Valley showed that American elderberry was stressed in that environment (Fyhrie et al. 2020). In the study, two cultivars of American elderberry planted in hedgerows grew and yielded substantially less in the first two growing seasons, and showed greater signs of heat or water stress (or both) during the hot summers, than blue elderberry planted in the same hedgerows (see sidebar 2 on p. 5). As a result of this trial, and in the interest of promoting more planting of native species, this guide focuses primarily on growing blue elderberry.

\section{Blue elderberry}

Blue elderberry's natural range extends throughout much of western North Ameri$\mathrm{ca}$-from British Columbia to Mexico, as far east as Utah and as far southeast as West Texas. Blue elderberry is deciduous and is adapted

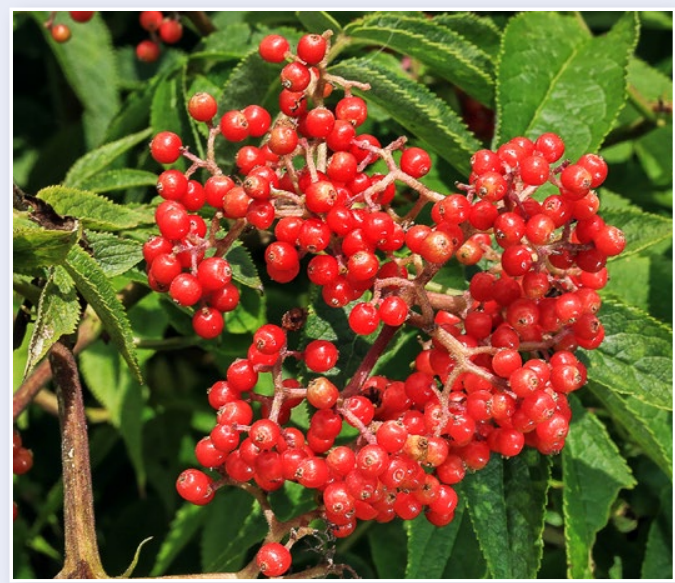

Sidebar 1 figure 1. Red elderberry cyme, showing the distinctly red color of the berries and the more conical shape of the cluster. Photo: W.D. and Dolphia Bransford 


\section{SIDEBAR 2}

\section{Evidence from the field: Comparing early yield and growth of blue and American elderberry}

A demonstration trial on three organic farms in Solano and Yolo counties in the Sacramento Valley observed 2-year growth and yield of blue elderberry started from seed and planted in irrigated hedgerows (Fyhrie et al. 2020). The trial also observed growth and yield of two American elderberry cultivars-Johns and Adams-started from prerooted cuttings and planted in irrigated hedgerows. Blue elderberry grew faster than American elderberry, with average height increases of 11 to 15 times in the first 2 growing years, depending on farm site, while American elderberry increased in height by only two to three times (sidebar 2 fig. 1). Blue elderberry also yielded substantially more than American elderberry in the second year, up to an average of over 11 pounds per plant on the highestyielding farm, compared to the highest average yield of just over 1 pound per plant for American elderberry. While it is possible that the blue elderberry enjoyed a head start in growth due to its being planted as seedlings rather than cuttings, the American cultivars also showed considerably more stress overall as the summer progressed, including

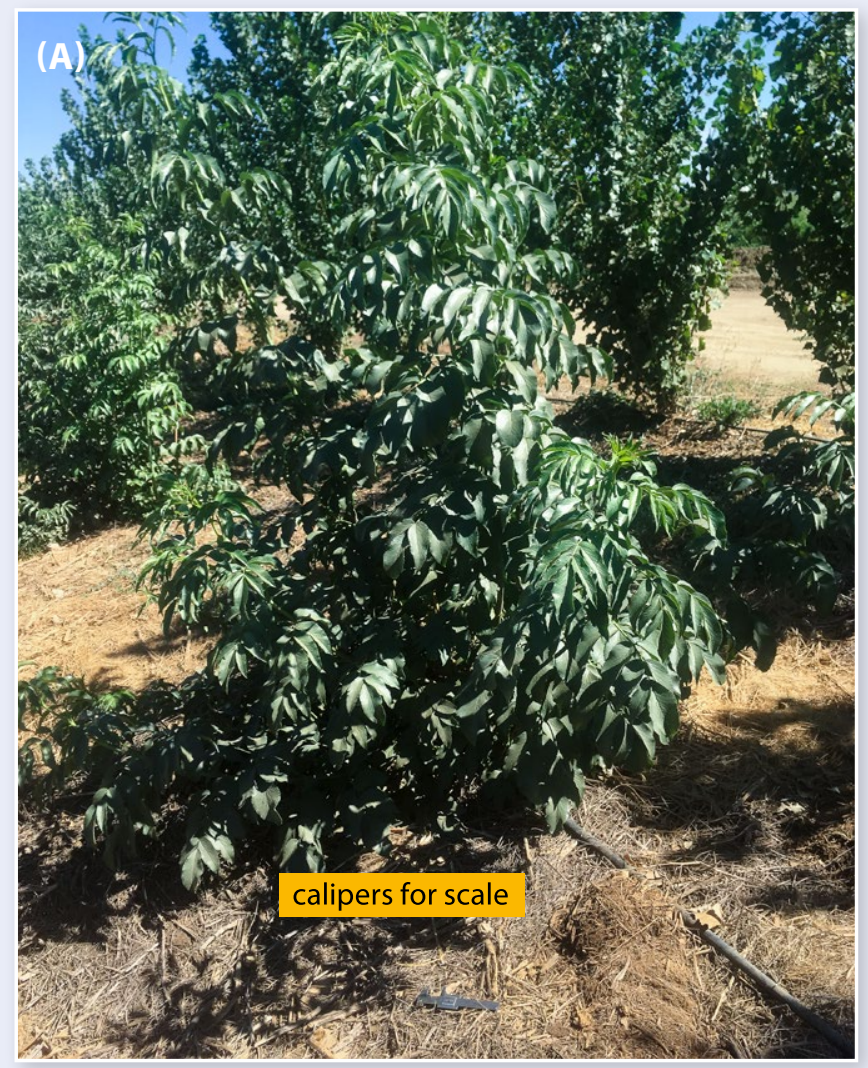

symptoms such as cupped leaves, withered flowers, and shriveling berries. Senescence also came much earlier for American elderberry (late August, as opposed to October or later for blue elderberry). In addition, informal observations in the third year (2020) showed that the American elderberry plants continued to be much smaller and less developed than the blue elderberry.

These observations suggest that American elderberry cultivars may not perform as well as blue elderberry in hedgerows in the Central Valley, especially when planted using methods suited to California native plants, including summer irrigation applied only every 1 to 4 weeks. American elderberry has a shallow, mat-like root system and is not considered very drought-tolerant (Charlebois et al. 2010). While the root systems of blue elderberry have not been studied, their apparent ability to tap into distant water sources suggests that their root systems may be deeper and more far-ranging than those of American elderberry. American elderberry is likely better suited to coastal and higher-elevation regions in California than to the Central Valley. Some farms in coastal counties have successfully tried American elderberry on a small scale, but systematic documentation of growth and yield potentials for different cultivars is not available.

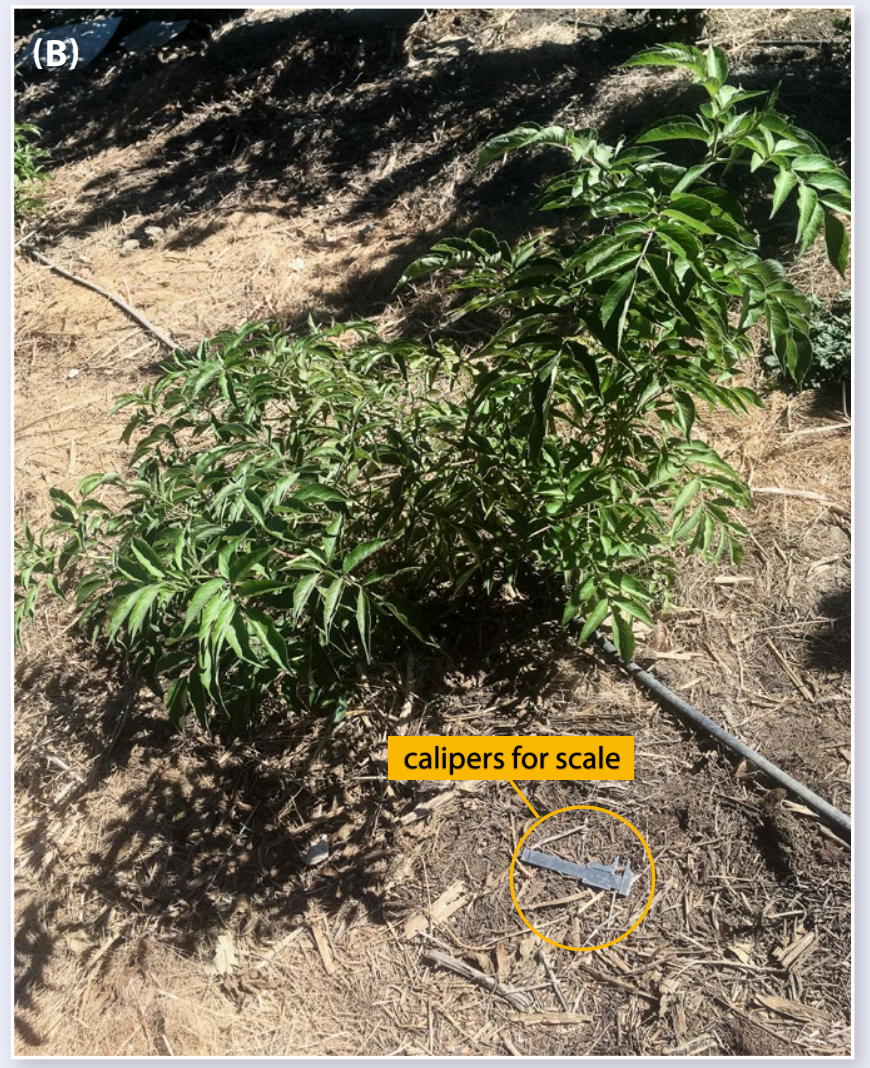

Sidebar 2 figure 1. Blue elderberry seedlings grew more vigorously than rooted cuttings of American elderberry cultivars Johns and Adams at field sites. Shown here are one blue elderberry (A) and one American elderberry plant (B) late in their first growing season. See the calipers on the ground, and poplar trees in the background of panel A, for scale. Photos: Katie Fyhrie 
to a wide variety of growing conditions. It is most often found at the edges or in the sunny openings of moist, forested areas (that is, in riparian forests, along stream banks, and at the bottom of slopes or canyons), as well as in drier habitats with access to moisture (Stevens 2001). Once established, blue elderberry tolerates dry conditions-but may drop leaves in late summer and fall in response to drought stress, then green up with winter rains (CNPS 2021a). Blue elderberry tends to go dormant in the winter in colder regions.

Blue elderberry can grow to be 20 to 30 feet tall and just as wide. Most plants grow as large tree-like shrubs, with many canes sprouting from the base, surrounding a thicker central trunk (CNPS 2021a; Maughan et al. 2018). Elderberry blooms throughout the season, with the biggest flush of flowers in the spring (March-May) (fig. 2). Berries ripen to dark blue in summer to early fall (June-October) (fig. 3). Blue elderberry occurs naturally in elevations from 3 feet to 10,000 feet (Stevens 2001). It can tolerate frost down to $5^{\circ} \mathrm{F}$, making it a suitable crop for a broad swath of

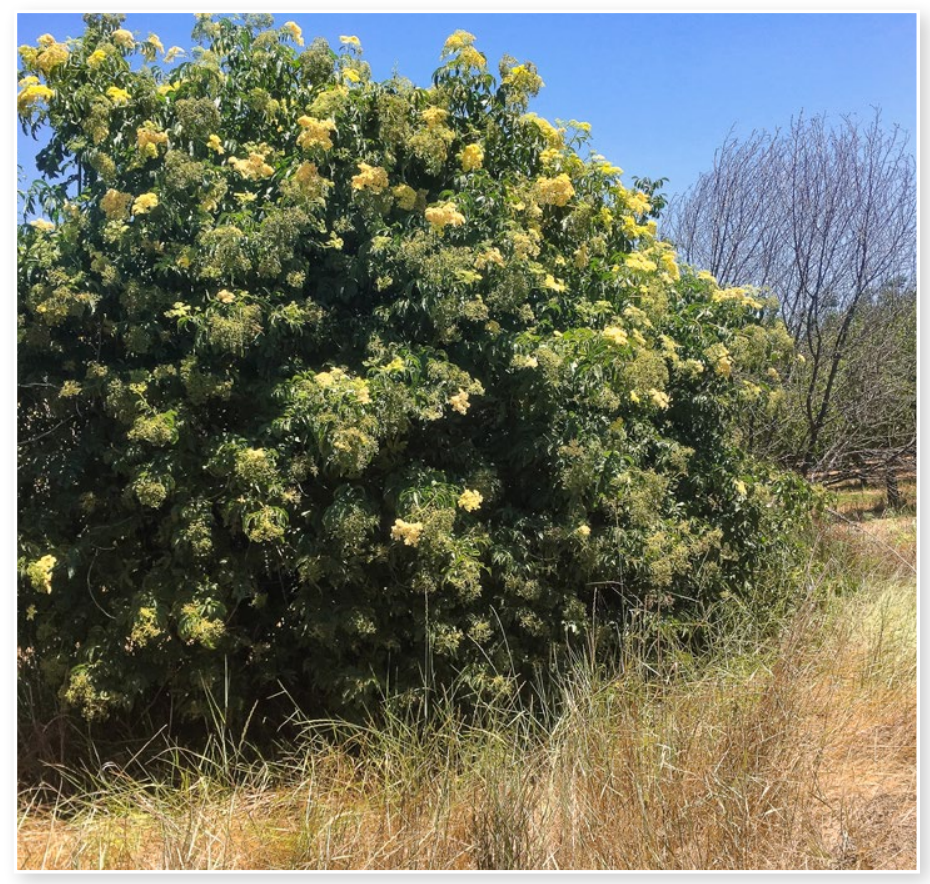

Figure 2. A mature blue elderberry plant in spring, when these California native shrubs are most easily recognized by their large, creamy flower cymes. The largest flush of flowers appears in spring, with the number of flowers gradually dwindling as the growing season progresses. A small number of flowers may continue to bloom as late as early October. Photo: Katie Fyhrie
California's topography, including coastal regions, the Central Valley, and foothills (Earnshaw 2018).

\section{How to grow elderberry in California}

This section covers the basics of growing elderberry in hedgerows, including site selection and sourcing of planting material, site preparation and planting, maintenance (weed control, pest management, and pruning), harvest, and postharvest handling. It also provides an overview of revenue potential.

Although European and American elderberry are produced commercially, and practices for growing these species are relatively well established, limited formal or peer-reviewed information is available about blue elderberry from a production perspective. Therefore, this section draws on knowledge of experienced California elderberry producers, a 2018-2019 field demonstration of blue and American elderberry planted in hedgerows on California farms (Fyhrie et al. 2020), commercial

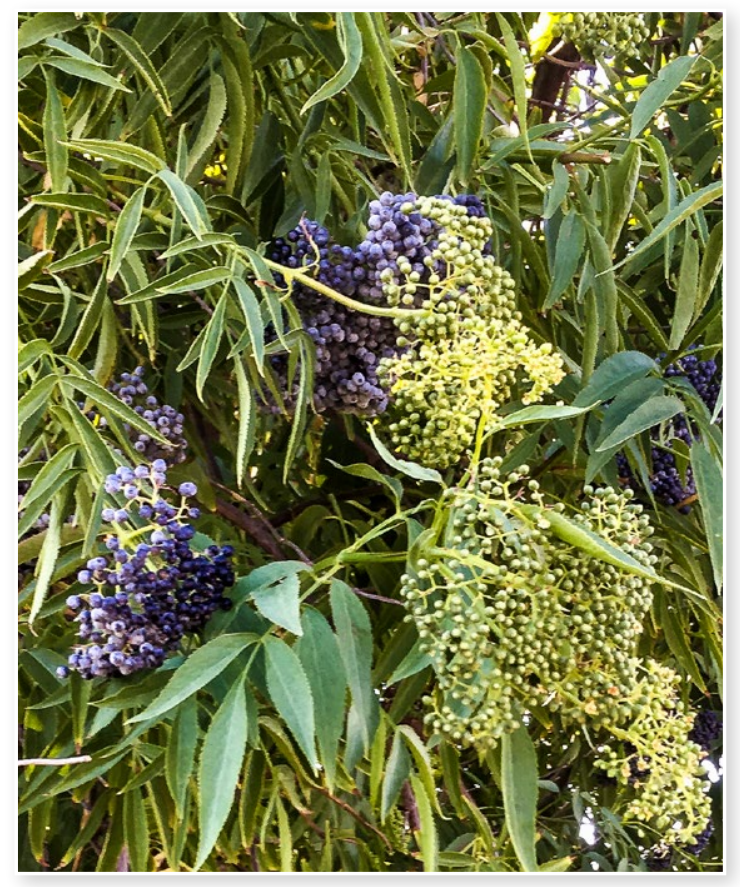

Figure 3. Close-up of a mature blue elderberry shrub during the summer harvest season. It is common to find ripe and immature fruit side by side, especially early in the harvest window, because blue elderberry sets fruit successively over a relatively long period of time. Photo: Katie Fyhrie 
production practices for American elderberry in other parts of the United States, and restoration ecology research.

\section{Planning}

Taking time well in advance to create a planting design for an elderberry hedgerow, evaluating the planting site, and considering plant procurement will help ensure the long-term success of the elderberry hedgerow.

\section{Planting design}

Plant spacing for elderberry depends on grower needs and interests. Wider spacing results in reduced pruning needs and larger shrubs with more berry clusters, contributing to higher yields per plant. Larger shrubs, however, can increase labor time because ladders are necessary for harvesting berries in the upper canopy (fig. 4). Wider spacing also permits more weed intrusion in open areas between shrubs-at least in the establishment years, when shrubs

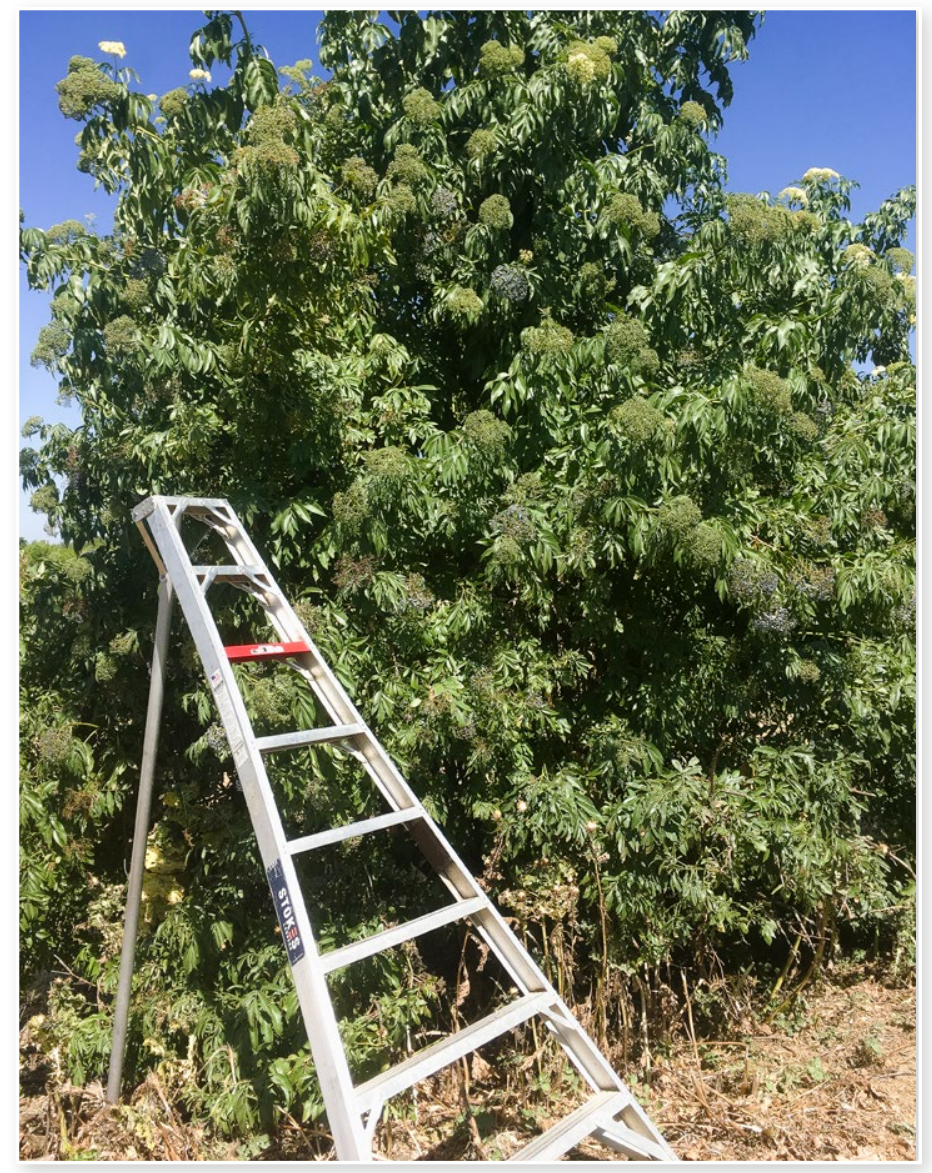

Figure 4. A mature blue elderberry shrub planted in 2012, with an 8-foot harvest ladder for scale. This shrub was harvested weekly in 2018 and 2019 as part of the field demonstration trial discussed in this article. Photo: Katie Fyhrie are not yet large enough to shade out weeds (Charlebois et al. 2010; Wilson et al. 2016). Narrower hedge-like spacings help shade out weeds sooner. They also result in smaller plants, allowing more berries to be harvested from the ground, which increases harvest efficiency. That said, dense rows can make weeding between plants more difficult, especially during the establishment stage, and more pruning to maintain plant health and yield may be required (Wilson et al. 2016; Byers et al. 2014). (For information on pruning restrictions in the Central Valley, see the section on elderberry and the Endangered Species Act, which starts on p. 19).

In the Midwest, American elderberry is generally grown in monoculture, with 1 to 12 feet between plants-but the approach generally recommended for balancing harvest efficiency with weed control and maintenance ease is to allow 6 feet between plants in each row and 12 feet between rows. This spacing also increases air circulation, which reduces disease pressure in humid areas (Wilson et al. 2016) though humidity-related disease pressure is not known to be a problem in California.

Elderberry in California hedgerows can be planted alone or in combination with other plant species. If blue elderberry plants are planted in a single line or with other large shrubs, recommended spacing ranges from 4 to 8 feet for denser hedges (Earnshaw 2018) and up to 15 feet for larger plants in a lower-density hedgerow (Long and Anderson 2010). Elderberry plants spaced at least 15 feet apart are more likely to approach their maximum size of 20 to 30 feet wide (CNPS 2021a); spacing plants more than 15 feet apart is an option that may increase ladder accessibility around the entire shrub. Small shrubs, forbs, and grasses can be planted between large shrubs, but may be shaded out eventually, especially with closer spacing of large shrubs. Smaller plants can also be placed in separate planting lines (Long and Anderson 2010; Earnshaw 2018) to prevent elderberry from shading them out. Alternatively, one can plant spreading species like yarrow, which will eventually migrate out of shady areas. 


\section{Site selection}

Planting sites for hedgerows should be on field edges, such as noncropped areas along roads, canals, fences, and field borders, or in weedy areas that need regular management. Sites should have access to water for irrigation and should be accessible to any equipment needed for ground preparation, planting, and maintenance. In the Central Valley, especially, it is also important to choose a site where the hedgerow can remain a permanent landscape feature; this recommendation is due to restrictions on removing elderberry plants, which host the threatened valley elderberry longhorn beetle. Exceptions to these restrictions can be made for growers who have entered into a safe harbor agreement (for more details, see the section on elderberry and the Endangered Species Act, starting on p. 19). Care should be taken when planting in areas where livestock may have access to the plants, as elderberry may have varying degrees of toxicity to animals.

Blue elderberry thrives in full sun to partial shade and tolerates full shade. It prefers soils with moderate or fast drainage and $\mathrm{pH}$ of 6 to 7 , but will tolerate many soil types and conditions (CNPS 2021a). As a riparian species, blue elderberry can tolerate flooding during the winter dormant season, especially in welldrained soils (Long and Anderson 2010). At higher elevations and in other areas prone to spring frost, choose locations that are slightly elevated above the surrounding landscape to avoid frost damage during budbreak and spring growth (Byers et al. 2014). A growing season of at least 85 frost-free days is required for blue elderberry production (Maughan et al. 2018).

Sites with severe weed infestations, especially aggressive perennial weeds like Johnsongrass, should be avoided unless weeds are adequately controlled with techniques such as solarization, which needs to be implemented over the course of a few summer months, prior to planting. To help prevent birds that perch and roost in the hedgerow from feeding on crop seedlings, separate crop fields from the hedgerow with an access road (Long and Anderson 2010; Earnshaw 2018). To protect elderberry, beneficial insects, and pollinators from herbicide and pesticide drift, choose a site that is sufficiently buffered from areas that are sprayed (Earnshaw 2018). Elderberry is known to be sensitive to dicamba, 2,4-D, and glyphosate (UM IPM 2017), but other herbicides may also cause damage.

\section{Planting time}

The best time for planting perennials in California is fall, when cooler, wetter conditions help plants get established before the heat of the next summer sets in. However, planting in early spring can succeed as long as irrigation water is available (Long and Anderson 2010; Earnshaw 2018). Planting should not be conducted amid extremely wet, cold, hot, or windy conditions because such conditions greatly reduce the chances of success (Earnshaw 2018).

\section{Sourcing plants}

Blue elderberry plants are available from some commercial nurseries in California, but larger plantings in some parts of the state may require growers to propagate from local genetic stock, either from seed or cuttings. This section describes all of these options, along with their advantages and disadvantages.

\section{Genetics}

Elderberry plants can be propagated by seeds or cuttings. Since blue elderberry does not have established cultivars, propagation from seed will result in genetically unique plants, with corresponding variability in flowering time, ripening time, and size of flower and berry clusters. To accommodate this variability, growers choosing to plant seedlings should consider planting somewhat more than they believe is needed to achieve their marketing goals.

Cuttings will result in genetically identical plants (clones). If consistency and predictability are highly important to growers, they should choose plants that are propagated clonally from established shrubs with favored traits.

Whether using seeds or cuttings, growers are advised, to the extent feasible, to source planting material from within their own regions of California-or to work with a nursery that is able to do so. Locally sourced planting material is best adapted to the area and its use will likely result in better establishment and healthier plants. Additionally, concerns exist among the native plant restoration community 
that introducing nonlocal genetics may negatively affect the resilience of existing native plant communities (Dorner 2002).

\section{Commercial sources}

Buying potted elderberry plants saves labor, eliminates the need for propagation infrastructure, and can guarantee healthy, disease-free plants. Depending on how many plants are needed at one time, however, a cost-effective commercial source may not exist in one's region. Commercial sources for blue elderberry plants in bulk are essentially limited to nurseries growing native plants for restoration projects. Growers interested in bulk purchases should contact neighbors to ask for suggestions about local nurseries-or contact the local office of the Natural Resources Conservation Service, or other organizations connected to native habitat restoration. In addition, the California Native Plant Society maintains the Calscape website, which includes listings of nurseries around the state that carry given species [for blue elderberry, calscape.org/Sambucus-nigra-ssp.-caerulea-(Blue-Elderberry)]. Contacting a nursery a number of months before the planned planting date is advised, as lower prices may be available if a contract grow is arranged. However, this option may only be available for larger plantings, as nursery contracts may involve a minimum order size.

More options exist for smaller blue elderberry plantings, including retail nurseries and those listed on the Calscape website. If shopping at retail nurseries, however, growers should confirm which subspecies they are purchasing, the propagation technique used, and the source of propagation stock. Due to recent taxonomic updates of the Sambucus genus (Stevens 2001), several outdated scientific names for each subspecies are still commonly found online and at nurseries. For example, blue elderberry (Sambucus nigra ssp. cerulea) may also be called Mexican elderberry, or may carry labels with previous nomenclature such as Sambucus cerulea, Sambucus glauca, Sambucus arizonica, Sambucus neomexicana (USDA 2021), or Sambucus mexicana (CNPS 2021a).

For those interested in trying American or European elderberry cultivars, hardwood cuttings, bare-root plants, and potted cuttings are available from a number of nurseries and growers in the Midwest, the Southeast, and the eastern United States. For larger American or European elderberry plantings, buying hardwood cuttings is the least expensive option, but this method requires rooting prior to planting. Contact the seller to confirm possible shipping dates and adjust the planting plan accordingly. Plants may not be available until spring.

\section{Propagation}

Propagating elderberry oneself requires labor and planning, but it may be the best option for growers who cannot find a good commercial source that meets their needs, and especially for growers looking for clonally propagated plants (from cuttings). For example, conservation- and biodiversity-focused growers may choose to propagate their own plants from plants growing very close to their locations, thus ensuring a locally adapted ecotype. Foragers may be interested in propagating their own plants from a favorite wild shrub for more convenient access and a larger harvest.

Growers who choose to propagate their own elderberry can choose among several methods. The primary recommended propagation methods are to use rooted hardwood cuttings or seed, but elderberry can also be propagated using semi-hardwood cuttings, softwood cuttings, digging suckers, and root cuttings (Charlebois 2010; Stevens 2001). California native plant nursery managers have reported more success with propagating blue elderberry by seed than by cuttings.

\section{Seed propagation}

For successful germination, seeds must be treated before planting. Without treatment, elderberry seeds can take from 2 weeks to as long as 2 to 5 years after planting to germinate (Maughan et al. 2018). Cold stratification for 60 to 90 days at $41^{\circ} \mathrm{F}$ significantly reduces germination time (Charlebois et al. 2010; Maughan et al. 2018), but germination rates may still be low (McDonough et al. 2018). However, blue elderberry seeds are very small (117,000-259,000 seeds/lb) (McDonough et al. 2018), and each small berry contains three to five seeds (Emery 1988), so it is possible to easily collect a large number of seeds to ensure that adequate numbers germinate. 
The procedure for seed removal and stratification is described below:

- To remove seeds

- crush fresh, ripe berries and cover with cool water

- soak, stirring and mashing occasionally, for up to 24 hours

- skim off fruit pulp and partially filled seeds floating at the top (fully mature, viable seeds are heavier and will sink to the bottom)

- strain and wash mature seeds at the bottom of the soaking container, using a fine sieve

- Dry seeds and store them, or move directly to the next step-cold stratification

- To stratify seeds

- spread seeds on a moist paper towel, fold, and store in a plastic bag in the refrigerator (peat moss, vermiculite, perlite, coffee filters, or similar media can also be used)

- keep seeds moist for the duration of the stratification period (60 to 90 days), and check periodically for signs of germination (if germination occurs, seeds should be sown as soon as possible) (Emery 1988)

Elderberry seeds can be stored dry at $41^{\circ} \mathrm{F}$ for several years, and may be viable for up to 16 years if stored properly (Stevens 2001). To improve the germination rate of stored seeds, soak seeds either in a 1-percent bleach solution for 1 week or in hydrochloric acid for 10 to 15 minutes, prior to the 2 - to 3 -month cold stratification treatment described above. Hydrochloric acid solutions, also sold under the name muriatic acid, are typically available at hardware stores. Be sure to read the labels thoroughly and use recommended personal protective equipment when handling corrosive acids. Managers of California native plant nurseries have reported success with the bleach and hydrochloric-acid treatments. More typical methods to scarify seeds (that is, to soften or break through the hard seed coat)_such as mechanical abrasion or hot water soaks-are reported not to work as well for elderberry seeds.

\section{Hardwood cuttings}

Blue elderberry has been shown to be more difficult to propagate from cuttings than European and American elderberry. Growers propagating blue elderberry should plan for relatively low rooting success from hardwood cuttings (Maughan et al. 2018), but may have higher success rates if cuttings are taken during bloom, rather than during winter dormancy. For dormant hardwood cuttings, storing the cuttings in a refrigerator (cold callusing) for as many as 14 to 18 weeks prior to rooting may increase rooting success rates (Maughan et al. 2018).

To propagate from a hardwood cutting

- Make cuttings at least 10 inches long, including at least two nodes from wood grown during the last growing season. "Heel cuttings" may be more successful (Stevens 2001). Heel cuttings are made by making an incision at the stem, directly above a suitable side shoot, and then gently pulling the shoot downward so that it comes away with a "heel" or "tail" of bark from the main stem (fig. 5). "Mallet cuttings" can also be used. Mallet cuttings are similar to heel cuttings but include a larger section of older stem wood around the base of the shoot.

- Treat the rooting ends of cuttings with rooting compound and place in pots with potting soil or a soilless medium such as perlite, peat moss, or sand, or in a prepared bed in soil. (Omit conventional rooting compound, or look for natural alternatives, if producing for a certified organic operation.)

- Keep moist until rooting occurs, then carefully transplant into pots (young roots are extremely fragile).

\section{Site preparation and planting}

Soil preparation, weed management, and irrigation play interrelated roles in ensuring the success of hedgerow establishment. This section describes a range of commonly used practices and their advantages and disadvantages.

\section{Soil preparation}

Soil preparation should begin with weed control, which reduces weed competition and saves labor during elderberry establishment. Depending on the weed species present and 
level of infestation, weed control may begin as much as a year in advance of planting. At minimum, the planting site should be disced prior to planting (Long and Anderson 2010). Rototilling or other additional tillage after discing creates a better planting bed, especially if the plants are small. If the soil is heavy or compacted, ripping the soil and adding necessary amendments are recommended (Earnshaw 2018). Consider forming raised
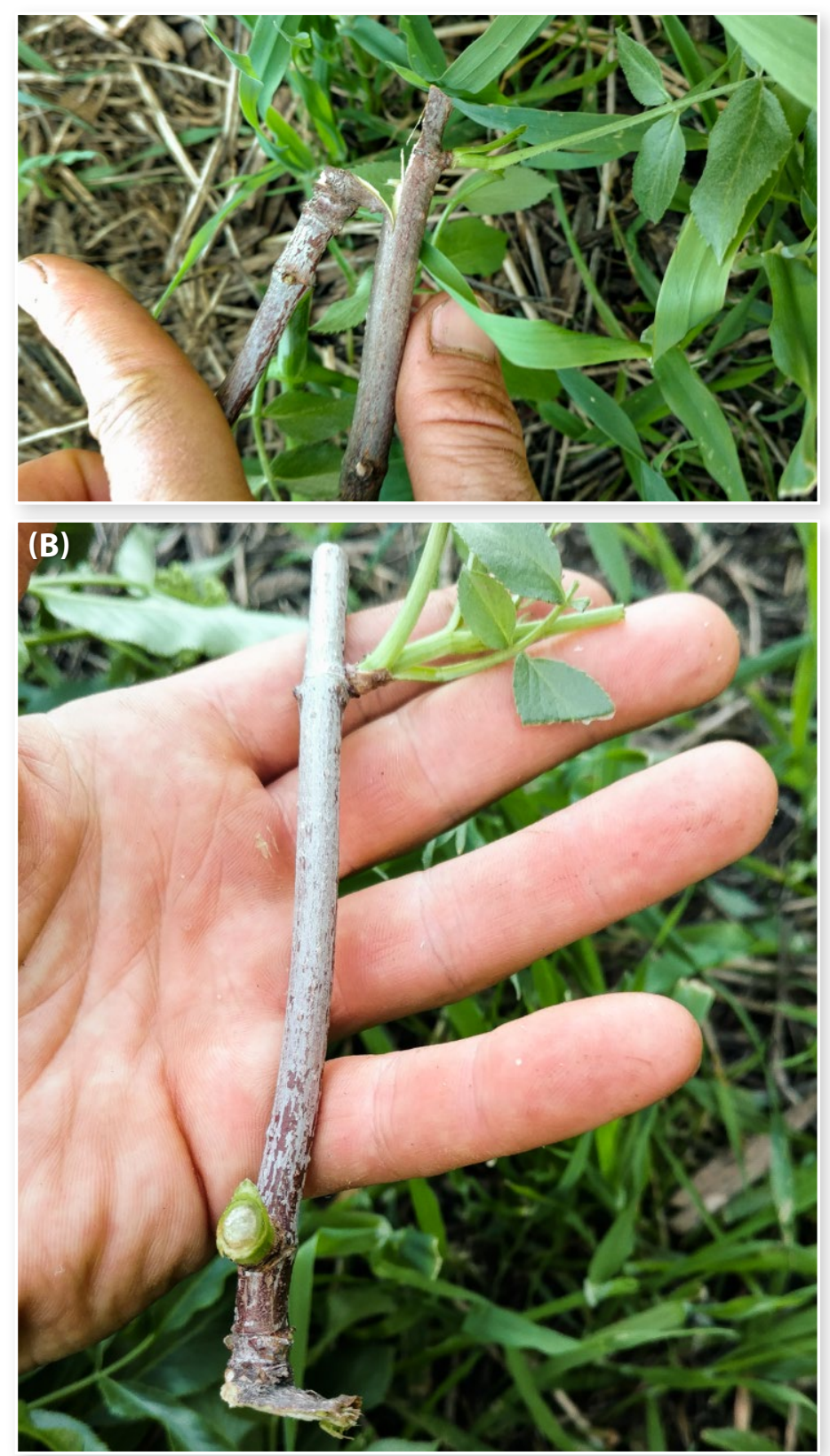

Figure 5. Heel cuttings of blue elderberry. When a side branch is cut partially through at its connection to the main branch, and then peeled away to leave a thin strip of bark from the main branch $(A)$, a heel cutting results $(B)$. The heel end should be treated with rooting hormone for greatest chance of success. Photos: Katie Fyhrie beds or berms for plants if growing in soils with poor drainage. Elderberry plants may also be planted without tillage by simply digging planting holes, but may grow better under such conditions if planted during the fall to take advantage of soil softened during the rainy season.

\section{Irrigation}

Make sure the planting site has access to water for irrigation, and install main irrigation lines and headers prior to planting. If using drip tubing with in-line emitters, place the drip tubing as well to avoid crushing plants later. For tubing with emitters added manually, it may be easier to wait and install them directly next to plants after planting, taking care not to crush plants.

Like other California native plants, blue elderberry needs summer irrigation approximately every 1 to 2 weeks for at least 3 years after planting to minimize loss and successfully establish plants (Long and Anderson 2010). Irrigating once per week is recommended for fastest growth in most parts of the Central Valley, especially in the first year. Sandy soils may require more frequent irrigation. In soils with high water-holding capacity, elderberry can thrive if irrigated less frequently than once a week. Approximately 6 to 10 gallons per plant per week over the summer months is recommended (Earnshaw 2018). The amount needed will vary substantially by region and soil type, with the higher amounts generally required in the Central Valley, where summer evapotranspiration rates tend to be substantially higher than in coastal regions. The key is to feel the soil regularly at a depth of at least 6 inches, or down to the plant's rooting depth. Alternately, use a soil moisture monitor to ensure that the soil in the plant's root zone remains moist (but not waterlogged).

Drip irrigation is recommended because it is efficient, reduces flooding damage to plants, and reduces weed pressure. Polyethylene irrigation tubing with one or two emitters installed at each plant, each emitting half a gallon to 1 gallon per hour, is recommended over drip tape with in-line emitters because of the former arrangement's durability and its ability to place water directly at the base of plants only. 


\section{SIDEBAR 3}

\section{Evidence from the field: Importance of site preparation for establishment success}

Site preparation-including both tillage and weed control-is one of the most important factors in establishing a successful elderberry planting. Tillage to open the soil and facilitate early root growth is especially important for spring planting, as was evident in a Sacramento Valley demonstration trial-in which three farms, all with silty clay loam or loam soils, used very different tillage methods prior to a spring planting (Fyhrie et al. 2020). One farm planted elderberry seedlings on previously uncultivated field edges, with no tillage, while the other two farms planted elderberry plants of similar size at the same time-one with deep-ripping and rototilling to address site-specific compaction problems and the other with discing and rototilling. After 3 months, the stem diameter of elderberry plants on the two farms that used tillage increased by 2.5 to 4 times more than did the stem diameter of plants at the untilled location. Similarly, the height of plants at tilled locations increased by 1.5 to 2 times more than did those at the untilled location.

The lack of early growth at the first farm was compounded by the farm's approach to weed management, which entailed placing cardboard and crop-residue mulch around each plant in an area whose diameter was 3 feet. The other two farms placed mulch across the entire hedgerow surface area. During the winter rainy season following planting, the first farm experienced such tall weed growth in the unmulched ground between elderberry plants that some of the small plants became entirely engulfed in weeds 6 feet tall (sidebar 3 fig. 1). The resulting stresses likely contributed to a rate of plant death during the rainy season three times greater than the death rate during the summer growing season. Although many elderberry plants survived these challenging conditions and continued to grow over the next summer, these setbacks could likely have been prevented with some tillage and more extensive mulching.

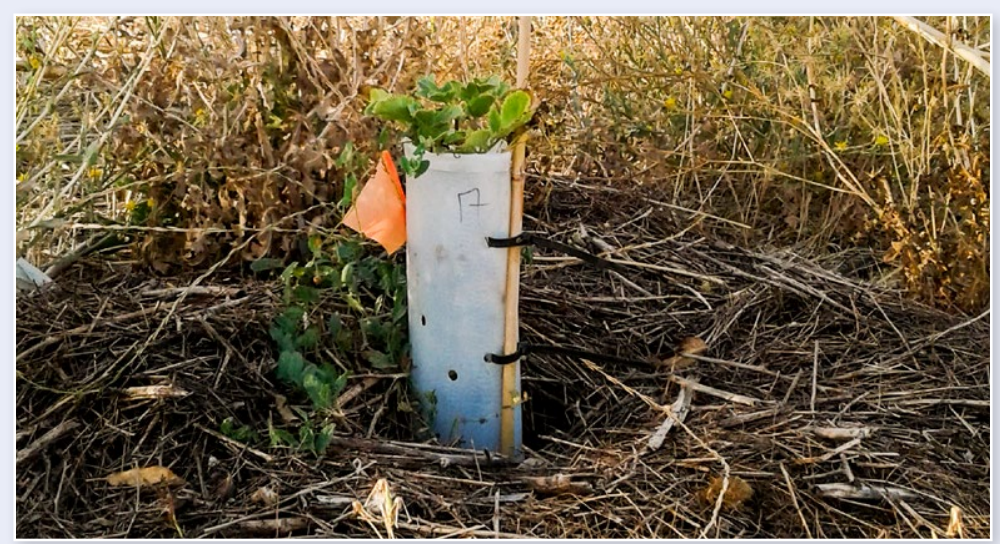

Sidebar 3 figure 1. Elderberry seedling in October after spring planting, surrounded by tall weeds. This planting limited mulching to a 3 -foot radius around plants. Photo: Sonja Brodt
Flood and sprinkler irrigation can be effective for elderberry, but will result in higher weed pressure. If using flood irrigation, take care not to include in your hedgerow other plants that do not tolerate standing water (Long and Anderson 2010; Earnshaw 2018). Pre-irrigating just prior to planting is ideal so that soil moisture will be available immediately for new plants (Earnshaw 2018).

In many parts of California, once a hedgerow has been established for 2 to 3 years, irrigation can be completely removed. Blue elderberry will benefit from occasional irrigation after establishment, but in many cases it is not necessary unless winter conditions are unusually dry. According to University of California (UC) Cooperative Extension Farm Advisor Rachael Long (personal communication, December 5, 2019), infrequent supplemental summer irrigation may be necessary in dry areas completely lacking subsoil moisture to tap into. (Such subsoil moisture might come from seepage from nearby streams, ditches, or irrigated cropland, or a high water table.) In general, eliminating summer irrigation of California native plants once they are established is recommended because warm, wet conditions can kill or shorten the lives of many species (CNPS 2021b). While blue elderberry may not be negatively affected by long-term summer irrigation, the risks of summer irrigation are worth noting if elderberry is planted in multispecies hedgerows alongside other native species.

\section{Mulch}

Installing an effective weed barrier is recommended to conserve soil moisture and help young plants outcompete weeds, but weeds will eventually be shaded out as elderberry plants mature. Keep irrigation lines on top of mulch to make identifying and fixing leaks easier. Many mulch materials can be used, including wood chips, straw, cardboard, plastic mulch, and landscape fabric (Earnshaw 2018) (fig. 6). Weed seeds will eventually germinate in or on top of any mulch. Whichever material is used, controlling weeds within and next to the hedgerow prior to seed production will significantly reduce future labor needs for 
weed control. Planting a living mulch between plants may also be effective.

Organic mulch such as wood chips, straw, rice hulls, or almond hulls should be spread at least 2 to 3 inches deep to control weeds. A layer of plain cardboard placed underneath a layer of organic mulch can act as an additional weed barrier. Lighter mulches may blow away in the wind-and some, like straw, have even been known to catch fire and burn the hedgerow (Rachael Long, personal communication, December 5, 2019). Growers should evaluate their planting sites and choose materials that suit their locations. The drawback of using inorganic materials such as weed mats or plastic mulches is that, once these materials are past their useful life, scraps of degraded material can significantly litter the area.

\section{Planting}

If using drip irrigation, make sure that plants are installed as close to an emitter as possible to ensure that young roots do not dry out. Water new plants deeply as soon as possible after planting. Installing plastic tree-protection tubes (fig. 7) at planting time can reduce damage
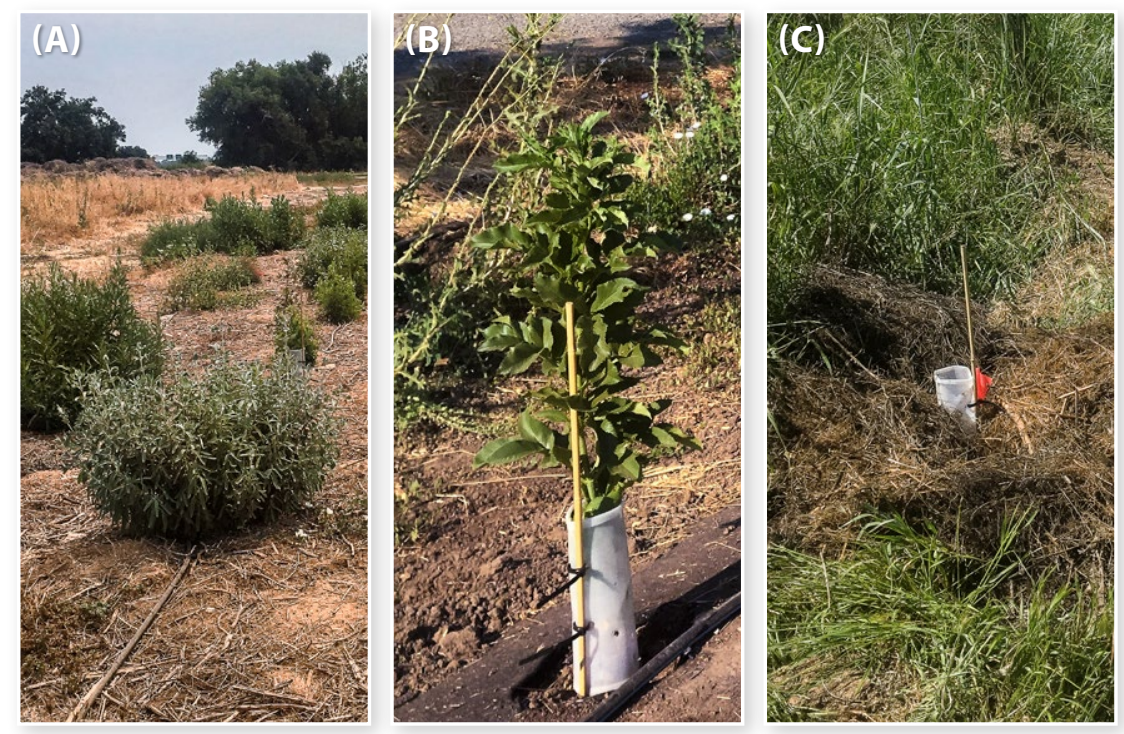

Figure 6. Organic mulch and plastic landscape fabric used on farms in the field demonstration trial during the first growing season. Farm 1 (A) laid a thick layer of partially decomposed asparagus fern on top of cardboard. Farm 2 (B) elected for woven plastic landscape fabric. Farm 3 (C), like Farm 1, used cardboard and partially decomposed asparagus. By winter after the first growing season, weeds had begun to germinate in the organic mulch at Farms 1 and 3-and at Farm 3, unmowed vegetation surrounding mulch circles easily overtook young plants. At Farm 2, the plastic fabric effectively suppressed weeds throughout the first 2 years after planting. Photos: Katie Fyhrie from vertebrate pests, such as rabbits, and from herbicide drift. Tree tubes or flags, simply by making the plant locations more obvious, can also protect plants from damage while growers or workers weed and walk in the area. Plastic tree tubes, however, while very commonly used, can also involve trade-offs in some situations. Temperatures can get extremely high inside the tubes, which might stunt plant growth. Some restoration professionals have found that birds, attracted by spiders and insects living inside the tubes, can sometimes get trapped there. In regions with cold winters, tree tubes can also increase the chance of winter injury. In any case, it is recommended that tree tubes be removed after 3 to 4 months.

\section{Maintenance}

Once the hedgerow is established, continued attention to weed control and any potential pest issues is recommended-especially during the first few years, until the plants have filled out the space. Pruning is not essential for strong yields and has not been studied much in blue elderberry, but may also assist in reaching the grower's goals (see the section on pruning that begins on p. 14).

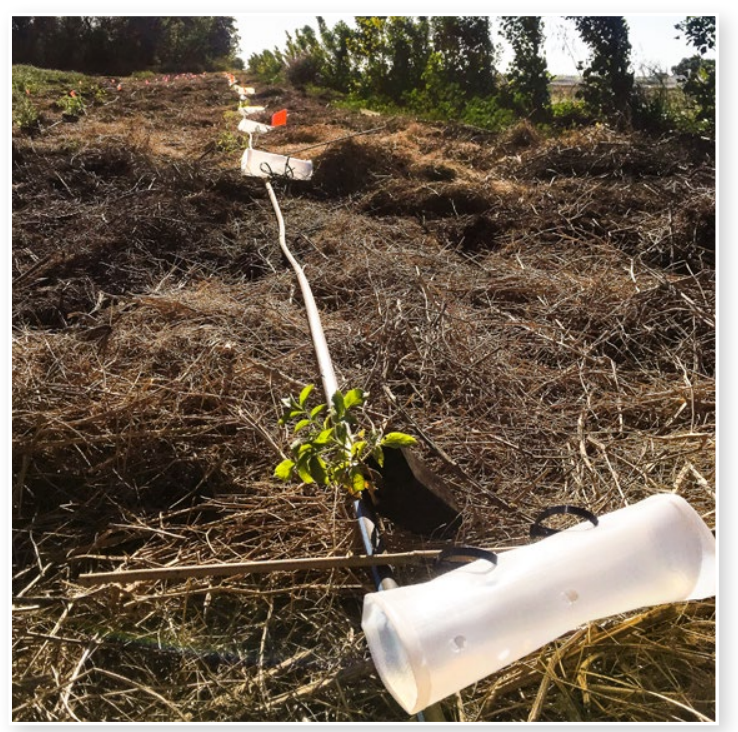

Figure 7. Blue elderberry seedlings in containers laid out for planting on Farm 1 in field demonstration trial. Seedlings were planted in holes punched through cardboard directly next to a 1-gallon-per-hour emitter. Pin flags and treeprotection tubes with bamboo stakes were used to mark and protect young plants. Photo: Katie Fyhrie 


\section{Weed control}

Weed competition is typically one of the biggest reasons that new plants become stunted or fail to establish. Proper weed control decreases plant loss and increases growth and vigor during the first few years of establishment, and may also increase plant longevity and health after establishment. Existing weed infestations should be controlled prior to planting to reduce weeding labor during establishment. Weeds should be carefully and consistently removed during establishment to minimize stunted growth and plant loss due to weed competition. Once established, however, elderberry shrubs effectively shade out weeds under their canopy. Growers should take care to control seed production from surrounding weedy vegetation, as seeds from nearby weeds will germinate and grow in mulch.

\section{Pests and diseases}

Commercial elderberry growers in the United States generally find that elderberry plants are relatively resistant to pest and disease. Spotted wing drosophila has caused significant yield loss for some Vermont elderberry growers (Wilson et al. 2016), and is now considered one of the most significant insect pests of American elderberries in the eastern United States. At the time of writing, we are not aware of any history of spotted wing drosophila being observed in blue elderberry in either the Central Valley or Central Coast region. If spotted wing drosophila infestation becomes a concern, however, mesh netting (with openings less than $1 \mathrm{~mm}$ across) installed over the entire planting during the first growing season is effective at excluding spotted wing drosophila (Wilson et al. 2016) - but will reduce the effectiveness of elderberry as habitat, since the netting will also exclude birds and other insects.

Birds are considered a significant pest by commercial growers of American elderberry (Wilson et al. 2016; Byers et al. 2014), and birds have also been observed to reduce yields in California. On the other hand, elderberries are a key summer food resource for many birds in California (Stevens 2001). To achieve a balance between profitability and biodiversity goals, growers might consider planting more elderberries than they need in order to share with wildlife.

Gophers and voles will also enjoy the hedgerow, especially if mulch is installed. They should be controlled to avoid girdling and root damage to elderberry plants (Earnshaw 2018). Vole populations may increase after a hedgerow is planted, but populations will decline over time, especially after 12 to 15 years (Golet et al. 2008). Installing barn owl boxes may help mitigate rodent pests (Lloyd and Baldwin 2021).

For elderberry, little is known about other possible pest and disease issues in California in particular, but the UC Integrated Pest Management Program lists aphids, elder borers, soft scale, canker diseases, leaf and stem spots, and heart rot as possible pest and disease issues for blue elderberry (UC IPM 2021). Other issues noted as significant in American elderberry in other parts of the United States include eriophyid mites and tomato ringspot, a viral disease, but neither of these problems has so far been observed or reported on blue elderberry in California. As in all cropping systems, the likelihood that these types of pest problems will become significant and spread throughout a planting is reduced when genetically diverse native species are grown as part of a biodiverse approach-such as the multispecies hedgerow model that is the focus of this guide.

\section{Pruning}

Elderberries are not dependent on pruning to produce abundant fruit, but most commercial elderberry growers in the United States prune their American elderberry regularly to maintain productivity and vigor, remove diseased or insect-infested wood, improve air circulation and sun penetration to control diseases, increase fruit size and quality, and shorten the harvest window (Wilson et al. 2016). Details of pruning techniques used by commercial American elderberry growers can be found in elderberry growing guides published by the University of Vermont (Wilson et al. 2016) and the University of Missouri (Byers et al. 2014). A pruning trial of American elderberry showed that annual selective dormant pruning resulted in the highest yield per plant, but that annual removal and biannual removal of all 
shoots were also effective strategies (Thomas et al. 2009). Selective pruning, in this case, means the removal of canes more than 3 years old to encourage vigorous new growth of 1- to 3-year-old canes, which are the most productive.

Traditionally, indigenous California tribes managed blue elderberry with fire to decrease plant density and increase fruit production (Anderson 2005; UC ANR 2021). Burning stimulates vigorous resprouting from the root crown (USDA 2021), and modern growers have achieved similar results from heavy pruning. As yet, no formal pruning trials of blue elderberry have been conducted.

California blue elderberry growers should check whether the site where they plan to plant elderberry falls within the range of the endangered valley elderberry longhorn beetle (see the section on elderberry and the Endangered Species Act, starting on p. 19). If the site falls within that range, pruning should be restricted to wood with a diameter of 1 inch or less, and should only be performed in the months of November to February.

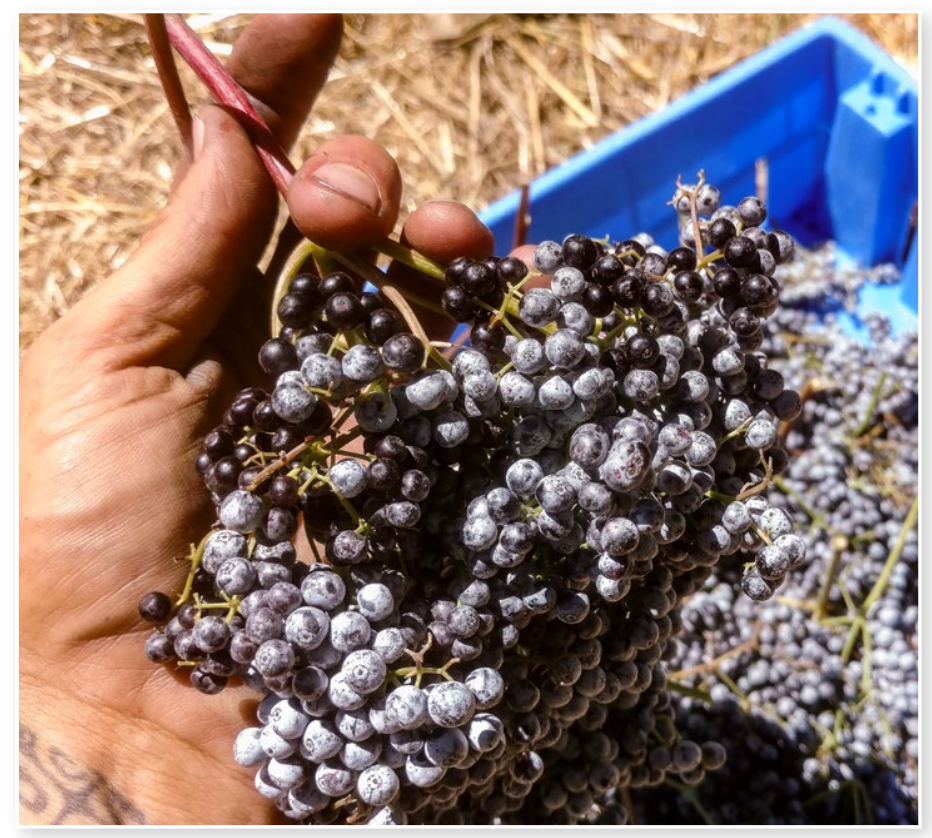

Figure 8. Ripe blue elderberry cyme harvested from an established blue elderberry shrub in Yolo County. Note that the waxy white surface bloom, which causes the berries to appear blue, has begun to fade around the edges of the cyme, revealing glossy, dark, purple-black berries. Cymes like these are more fully ripe than those whose bloom has not yet begun to fade. Photo: Katie Fyhrie

\section{Harvest and postharvest handling}

Harvesting berries and flowers at just the right time in their development is critical to obtaining a high-quality product. Also critical are proper postharvest handling and processing to remove toxins and preserve healthful compounds.

\section{Harvest}

No mechanical elderberry harvesters are available as of yet. Flowers and fruit are harvested by simply pinching or cutting entire cymes off the shrub by hand.

When just ripe, the berries of blue elderberry plants develop a dusty white bloom. As the berries continue to ripen on the shrub, the bloom will fade, leaving shiny, dark, blue-black berries (fig. 8). Blue elderberries can be harvested at any point after the bloom develops, but berries are generally sweeter and more evenly ripened if harvested after the bloom begins to fade. The berries of American (fig. 9) and European elderberry do not develop a bloom. Harvest whole cymes once all the berries in the cyme are blue-black. Cymes should not be harvested if any of the berries are

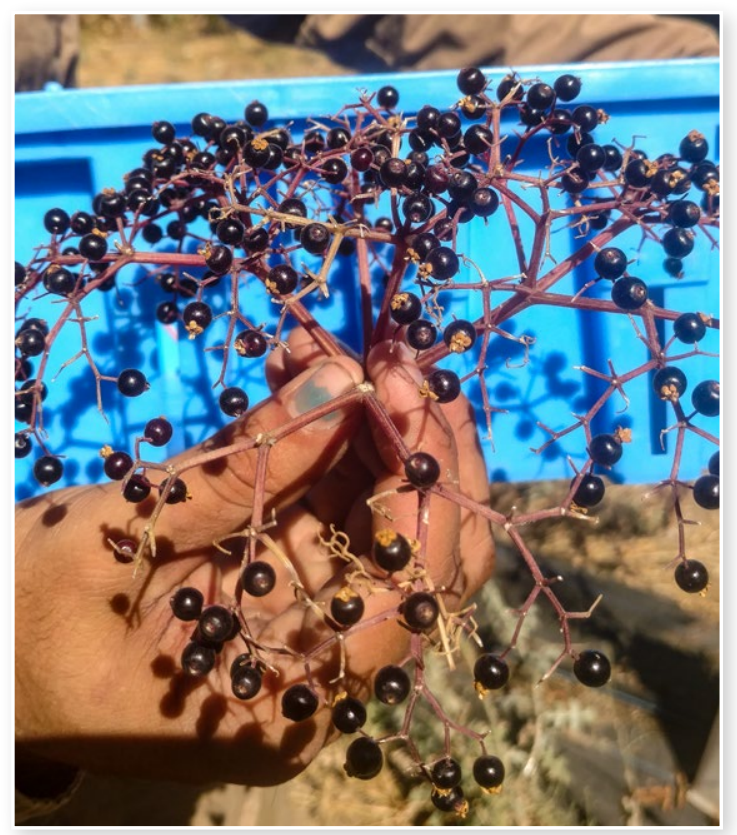

Figure 9. Ripe American elderberry cyme. During the field demonstration trial, ripe American elderberry cymes were frequently filled only partially, as shown here. Note the lack of a waxy white bloom on the surface of the berries, which is typical of American elderberries and distinguishes them from blue elderberries. Photo: Katie Fyhrie 
green or have a green tinge. This will ensure good, consistent flavor and will minimize the presence of cyanogenic glycosides, toxic compounds that may be present in unripe berries, as well as in the foliage and stems.

Flowers will have the best flavor if harvested when freshly opened. Blue elderberry flowers are creamy yellow when they first open (due to the presence of copious, fine, yellow pollen), and will gradually fade to white as fruit set progresses.

\section{Postharvest and processing}

Stems should be removed from berries and flowers before processing in order to remove possible sources of sambunigrin, a toxic cyanogenic glycoside compound. A mechanical destemmer used for destemming American elderberries is available for purchase from a producer in the Midwest (River Hills Harvest), but the cost is likely prohibitive for individual, small-scale production. A similar design can be achieved by creating a shaker table using perforated metal or wire screening with holes just larger than the diameter of the berries. The perforated screen can be shaken by hand or mounted to a reciprocating saw to motorize it. Some California processors have also been experimenting with modifications of grape destemmers that involve removing one of the

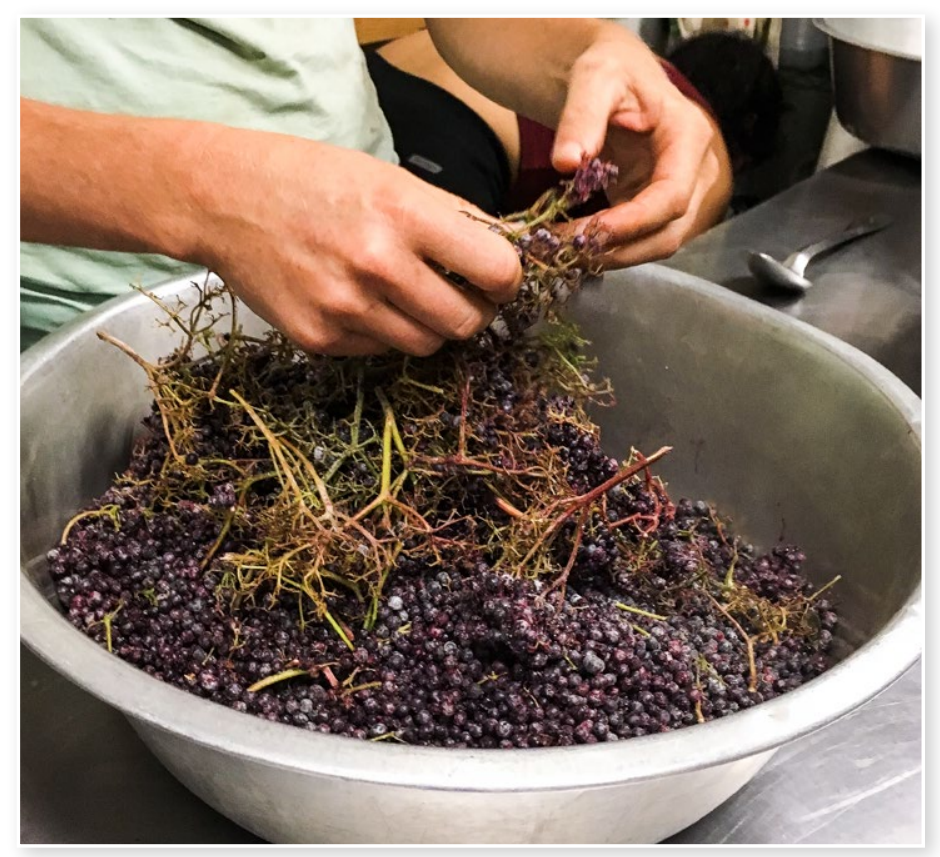

Figure 10. Destemming frozen berries by hand. Photo: Gwenael Engelskirchen crushing wheels, installing a basket with smaller perforations, and reducing the speed. However, destemming fresh blue elderberries using these methods has not been formally tested.

An easy method for entry-level and very small-scale production is to cool harvested cymes, then freeze them whole. The frozen berries fall easily from the stems when shaken in a bag, and stems can then be removed by hand (fig. 10). Flowers can be removed while fresh with a fork or comb, but they are easier to remove if the cymes are dried first. The flowers retain more aroma, flavor, and color if dried in full shade. Dried cymes can be poured into a bag and shaken to remove stems (as with frozen berries), or dried flowers can be removed using fingers, a fork, or a comb.

Berries should be heated during processing. European elderberry is known to contain substantial amounts of sambunigrin, a compound that can cause nausea, vomiting, weakness, and dizziness due to its conversion to hydrogen cyanide after ingestion (Senica et al. 2016). Immature fruit, leaves, and stems have much higher sambunigrin levels than fully ripe fruit, and heating during processing effectively reduces sambunigrin levels to amounts deemed safe to consume in normally accepted serving sizes, as the human body has some natural capacity to break down a limited concentration of cyanide (Senica et al. 2016). Because of heat's effect on elderberry, a small amount of green stems, leaves, and berries or buds is acceptable in destemmed berries and flowers. Preliminary results from research on American elderberries conducted at the University of Missouri found only low levels of cyanide in fresh berries and extremely low levels in juice and seeds. Levels in stems and green berries were relatively higher, but still much lower than those in samples of European elderberry tissues (Appenteng et al. 2021). No analyses of sambunigrin or cyanide levels have yet been conducted in blue elderberry.

Unfortunately, medicinal components of elderberries also break down during processing (Senica et al. 2016). Processors must balance the need for heat application to reduce sambunigrin levels with the desire to maintain medicinal anthocyanins and other compounds. 


\section{SIDEBAR 4}

\section{Evidence from the field: Harvest window, yield distribution over time, and harvest frequency for blue elderberry}

A Sacramento Valley field demonstration trial showed that both 2-year-old blue elderberry plants and older, wellestablished, unirrigated shrubs have a long harvest window, from approximately mid-June through late September (Fyhrie et al. 2020). Newly established American elderberry cultivars ripened later (early August) and had a shorter harvest window (approximately 1 to 1.5 months).

In their second growing season, yield of blue elderberry seedlings (planted in 2018) peaked in early August (sidebar 4 fig. 1A), as did that of established elderberry shrubs planted in 2008. Established elderberry shrubs planted in
2012 and 2014 both peaked slightly earlier, in mid-July (sidebar 4 fig. 1B). The differences may be due to the relatively drier conditions of the two established hedgerows-the 2008 elderberries were planted in a hedgerow adjacent to an irrigation ditch. Average per-plant yield of young American elderberry cultivars was highest in early August to mid-August.

Blue elderberry fruit seems to hold on the branch longer than the fruit of American elderberry cultivars, and may be suitable for biweekly or even monthly harvest. During weekly harvests, berries on American elderberry cultivars would ripen and dry out within 1 week. None of the blue elderberry harvest was lost to withering, and ripe fruit on nearby established blue elderberry shrubs did not start to dry out significantly until late summer and early fall.

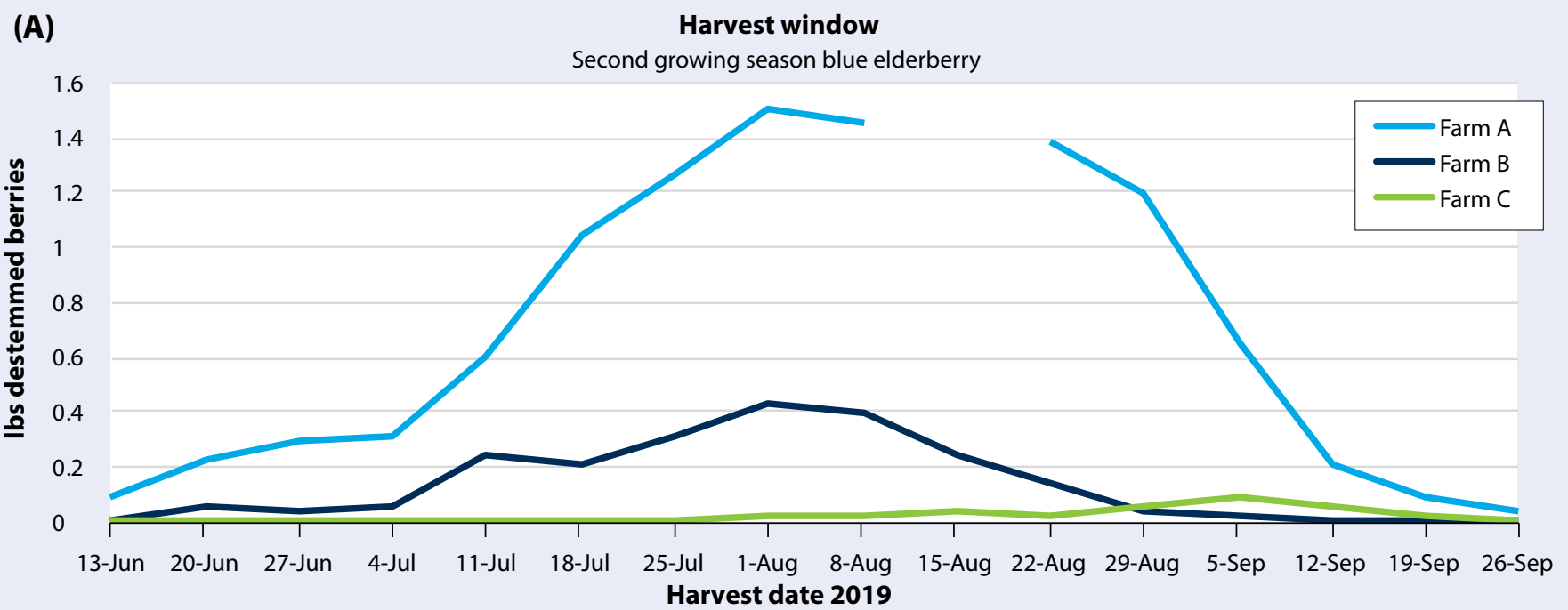

(B)

Average yield

Mature, un-irrigated blue elderberry

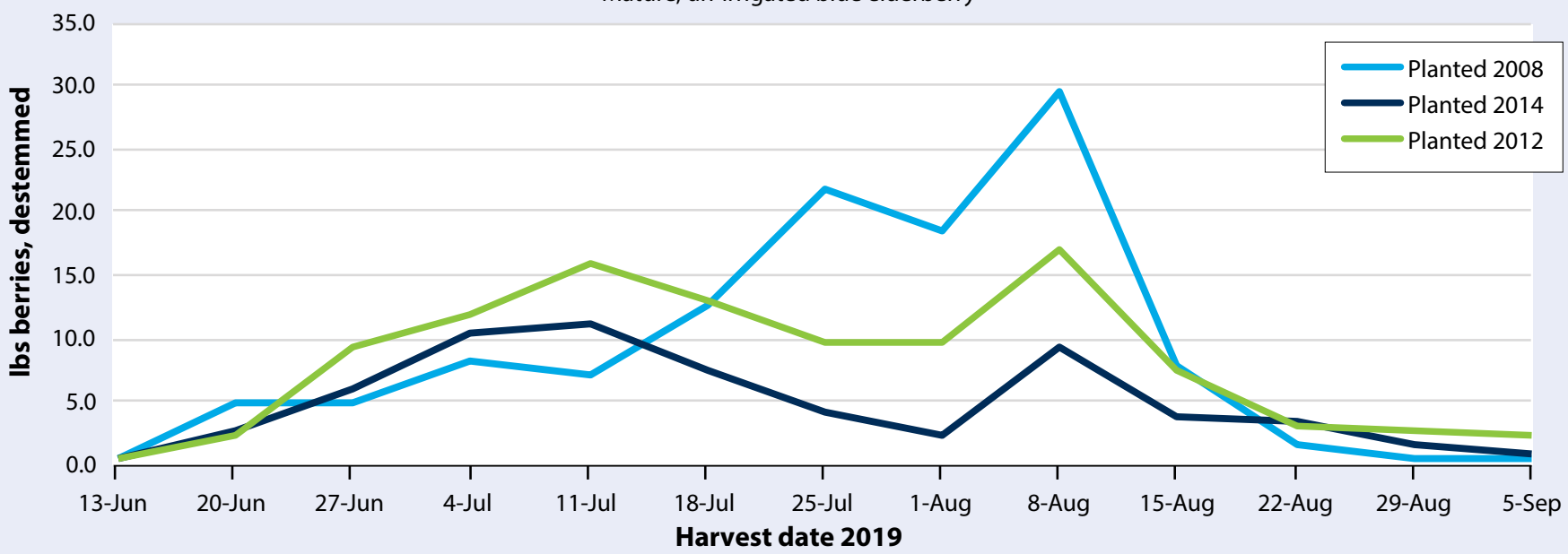

Sidebar 4 figure 1. Average per-plant yield (lbs, destemmed) of blue elderberry seedlings in their second growing season on three field study farms (A): average of 11.2 pounds total per plant at Farm 1, 2.2 pounds at Farm 2, and 0.3 pounds at Farm 3. Ripe berries were harvested weekly in 2019 (the gap indicates missing data). Average per-plant yield (lbs, destemmed) in the 2019 harvest season of established blue elderberry planted in 2008, 2012, and 2014 (B). 
Storage can also affect healthful anthocyanin and polyphenol levels. Johnson et al. (2015) found that these compounds decreased significantly in elderberry juice after three months of frozen storage, and that levels continued to decrease over time. Growers, distributors, and processors should minimize cold storage time before processing to maximize potential health benefits.

\section{Costs and potential revenue}

Costs to establish 1,000 feet of a single, 10-foot-wide row of blue elderberry can vary from approximately $\$ 1,000$ to $\$ 2,200$ (2018 values), depending on choice of tillage, plant spacing, and use of soil amendments and mulch, as well as labor costs (Brodt et al. 2020a, 2020b, 2020c). These costs account for the elderberry plants only. For diverse, native, multispecies

\section{SIDEBAR 5}

\section{Evidence from the field: Plant spacing and yield of mature blue elderberry}

Established blue elderberry shrubs in unirrigated hedgerows are highly productive, but yield can vary greatly between individuals. The amount of space between the harvested shrub and neighboring large shrubs and trees appears to have an effect on yield, although many factors can contribute to such variability. In a 2018-2019 Sacramento Valley harvest trial of mature, unirrigated elderberry plants, the lowest-yielding shrub (planted in 2008) yielded 58 pounds of berries and was spaced approximately 12 to 15 feet from another elderberry shrub (Fyhrie et al. 2020). Where the two shrubs had grown into one another, fewer live shoots, leaves, and berries were present, and the shrubs themselves were relatively small. Two higher-yielding shrubs, also planted in 2008, and with no other large shrubs or trees growing within 20 to 30 feet of them, yielded 126 and 171 pounds, respectively (sidebar 5 table 1). These individuals were much larger than the lowest-yielding shrubs, and bore fruit around their entire circumference. (Note that all harvests were limited to berries reachable from an 8-foot ladder, and therefore did not include all berries borne by these very tall shrubs.)

Growers planting blue elderberry more closely will likely see lower maximum per-plant yields - though it is possible, as with other orchard crops, that total per-hedgerow yield of mature plants may eventually be higher with closer spacing. However, growers of American elderberry have also found that elderberry shrubs, when planted too denselyespecially if less than 5 or 6 feet apart-produce fruit of reduced size and quality. Where the density threshold for blue elderberry lies has not yet been determined. However, for the overall health and ecosystem functionality of the hedgerow, we recommend wider spacing to allow integration of other species. hedgerows that include grasses and forbs, as well as diverse shrubs and trees, establishment costs should be expected to range from $\$ 1$ to $\$ 4$ per linear foot. For more information on establishment costs for native multispecies hedgerows in California, we recommend the following resources:

- Earnshaw, S. 2018. Hedgerows and farmscaping for California agriculture: A resource guide for farmers. 2nd ed. Davis: Community Alliance with Family Farmers, caff.org/hedgerows-farmscaping-forcalifornia-agriculture-guide.

- Long, R., and J. Anderson. Establishing hedgerows on farms in California. 2010. Oakland: UC Agriculture and Natural Resources Publication 8390, anrcatalog. ucanr.edu/Details.aspx?itemNo=8390.

Sidebar 5 table 1. Actual and average perplant yield of established blue elderberries by planting year.

\begin{tabular}{|c|c|c|}
\hline $\begin{array}{l}\text { Year } \\
\text { Planted }\end{array}$ & $\begin{array}{l}\text { Yield of individual } \\
\text { plants sampled* } \\
\text { (pounds/plant) }\end{array}$ & $\begin{array}{l}\text { Average yield } \\
\text { (pounds/ } \\
\text { plant) }\end{array}$ \\
\hline \multirow[t]{3}{*}{2008} & 58 & \multirow[t]{3}{*}{118} \\
\hline & 126 & \\
\hline & 171 & \\
\hline \multirow[t]{3}{*}{2012} & 42 & \multirow[t]{3}{*}{105} \\
\hline & 116 & \\
\hline & 156 & \\
\hline \multirow[t]{3}{*}{2014} & 43 & \multirow[t]{3}{*}{63} \\
\hline & 68 & \\
\hline & 78 & \\
\hline
\end{tabular}

Note: These shrubs are growing in three Yolo County hedgerows with no direct irrigation. Each planting year represents a separate hedgerow. All ripe berries within approximately 10 to 12 feet of ground level were handpicked, using an 8-foot orchard ladder. These unpruned shrubs averaged approximately 15 to 20 feet in height, and any berries beyond the reach of the ladder were not harvested. Source: Fyhrie et al. 2020

* Yield is pounds of destemmed berries, harvested weekly in 2019. 
Labor to harvest and destem elderberries by hand, at wage rates of $\$ 15$ per hour, will cost at least $\$ 1.39$ per pound of destemmed elderberries (table 1). These costs can be expected to decrease over time if the farm is able to invest in mechanized destemming equipment, as described above. In 2020, prices for bulk, certified-organic frozen elderberries were published at $\$ 5$ per pound by the Midwest Elderberry Cooperative. In the Sacramento Valley demonstration trial, the first harvest-which occurred in the second year after

Table 1. Cost of labor for harvest and destemming

\begin{tabular}{|l|c|c|}
\hline Activity & Minutes/pound & Dollars/pound \\
\hline Harvesting & 2.77 & 0.69 \\
\hline Destemming & 2.80 & 0.70 \\
\hline Total & 5.57 & 1.39 \\
\hline
\end{tabular}

Note: This table shows average the amount and cost of harvest and destemming labor per pound of destemmed berries, where labor costs $\$ 15$ per hour. Frozen berries were destemmed by hand. Harvest labor includes orchard ladder use. Berries were harvested by hand-plucking whole berry cymes. For a more complete accounting of costs of establishment and early returns in three elderberry hedgerow styles, refer to UC Davis Cost and Return Studies, coststudies.ucdavis. edu, and search for "blue elderberry."

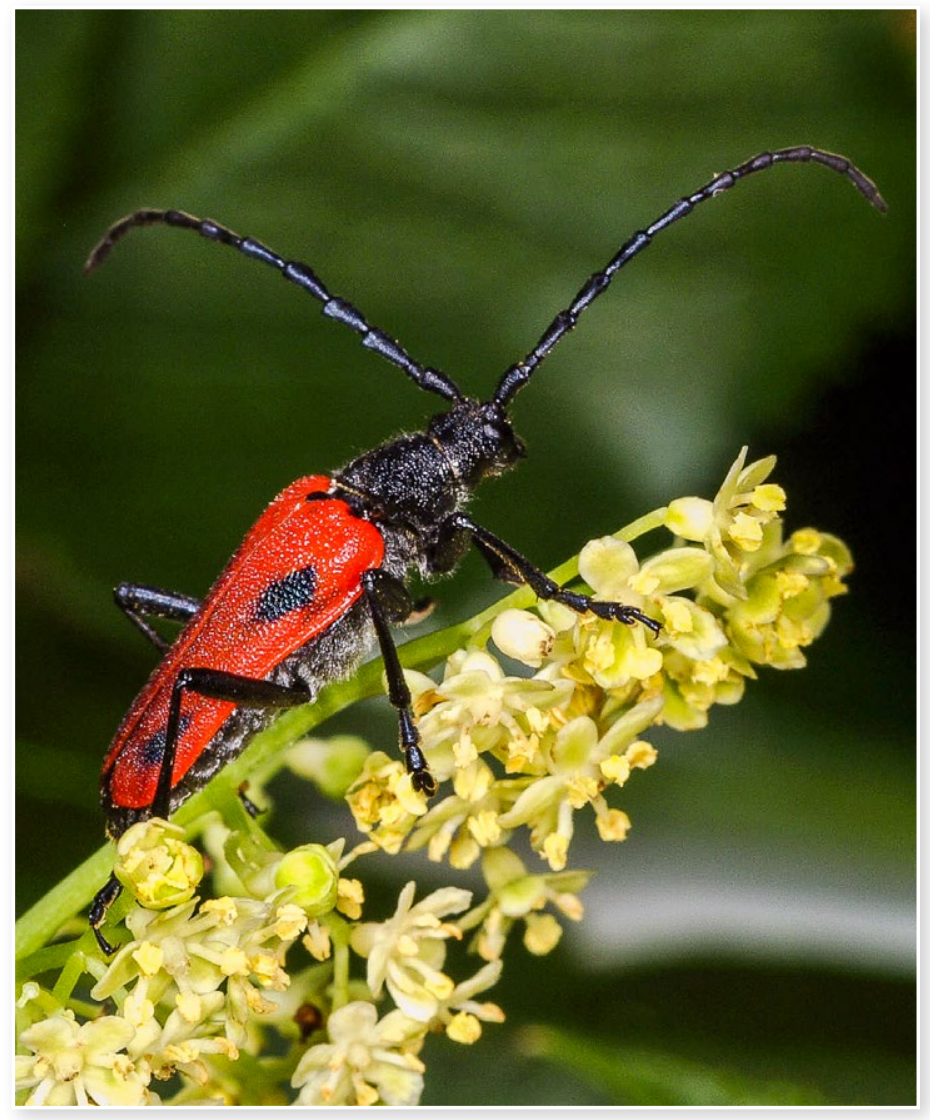

Figure 11. Adult male valley elderberry longhorn beetle. Photo: Jon Katz and Joe Silveira. Source: U.S. Fish and Wildlife Service planting-yielded 9 to 13 pounds per plant, or 864 to 1,248 pounds for a 1,000 -foot hedgerow (Fyhrie et al. 2020). At these yields, gross revenues would range from $\$ 4,320$ to $\$ 6,240$, or $\$ 3,119$ to $\$ 4,505$ after accounting for harvest and destemming costs. Given that this trial also documented mature elderberry yields ranging from 36 to 119 pounds per plant, revenues could potentially increase by four to nine times as the hedgerow matures. Finally, evidence from small-scale local herb buyers in California indicates that local sales of fresh elderberries can command significantly higher farm gate prices, from $\$ 16$ to $\$ 18$ per pound in 2020 , providing for much higher potential revenue.

\section{Elderberry and the Endangered Species Act: What you need to know}

Blue elderberry (along with red elderberrysee sidebar 1 on p. 4) is the obligate host for the valley elderberry longhorn beetle, meaning that blue and red elderberry are the only known plant species on which this beetle relies for habitat and food (fig. 11). Females lay eggs on leaves or at the junctions of leaf stalks and the main stem. Upon hatching, larvae bore into the elderberry stem, where they feed on pith and undergo several developmental stages, which together can last for up to 2 years. After pupating, the adults emerge from exit holes, feed on elderberry leaves and flowers, and mate and lay eggs - with all of these activities occurring from March to July (USFWS 2017).

As of 2017, experts consider the range of the beetle to extend from approximately Shasta County in the north to Fresno County in the south, including only the floor of the Central Valley and adjacent lower foothills. The majority of documented beetle occurrences have been below 500 feet in elevation (fig. 12). The valley elderberry longhorn beetle is listed as a threatened species under the federal Endangered Species Act, indicating that, while it is not in immediate danger of extinction, its populations have declined to the extent that federal regulations govern management of its 
habitat wherever it is found (USFWS 2017). The beetle is not necessarily present in every elderberry plant-but because larvae can stay inside stems for long periods, the elderberry longhorn beetle's use of any particular plant is rarely apparent in any event.

\section{Key federal regulations}

Because valley elderberry longhorn beetle larvae bore into elderberry stems, a few key regulations apply to any elderberry plant within the Central Valley range of the beetle (USFWS 2017):

- Elderberry stems larger than 1 inch in diameter may not be cut from the plant or removed from the site.

- Any required trimming (of stems less than 1 inch in diameter) should occur between November and February.

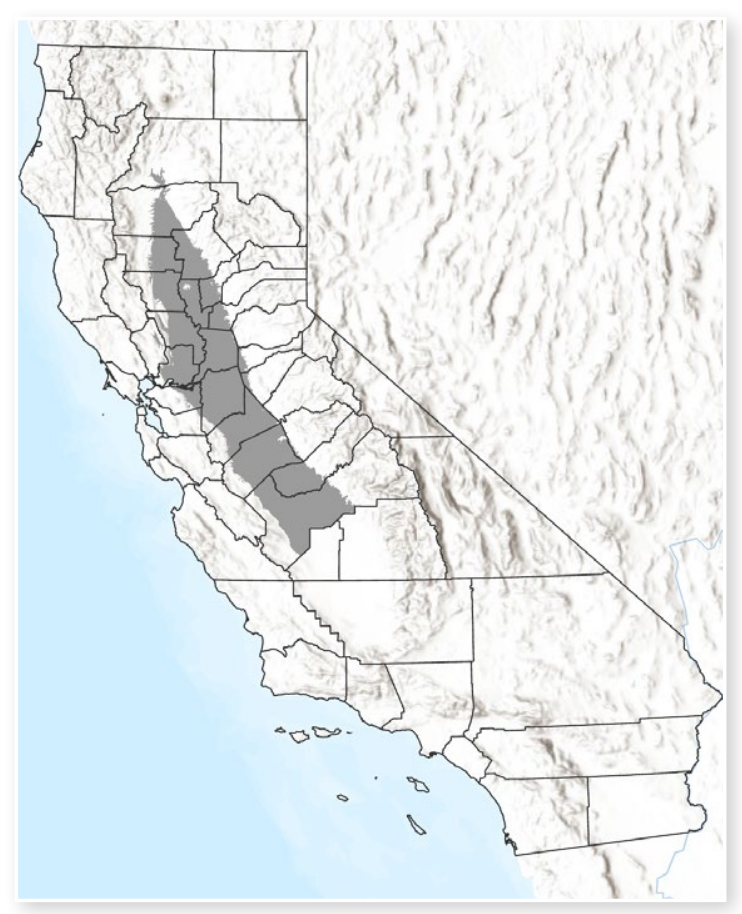

Figure 12. Map of California, showing the area of the Central Valley below 500 feet in elevationalso the suspected range of the valley elderberry longhorn beetle. Note: This map is provided for general reference only and is not to be construed as a definitive determination of the presence of the valley elderberry longhorn beetle. For specific guidance on the presence of the valley elderberry longhorn beetle in any specific area, contact local officials of the U.S. Fish and Wildlife Service. Source: UC ANR Informatics and GIS Program
Harvesting of flowers or berries is not restricted in any way. Due to restrictions on trimming and removing plants, producers wishing to grow blue elderberry are advised to limit planting of elderberry to hedgerows, where the plants become part of a permanent conservation feature with no expectation that major pruning or whole-plant removal will be required in the foreseeable future (unless the land has been entered into a programmatic safe harbor agreement).

\section{Programmatic safe harbor agreements}

A few areas of the Central Valley provide landowners with an alternative avenue for managing elderberry-programmatic safe harbor agreements. These agreements are typically made between the U.S. Fish and Wildlife Service and an administering organization, such as a nonprofit or other local community-based organization. Since 2013, privately owned properties in Butte, Colusa, Glenn, Shasta, Sutter, Tehama, and Yolo counties have been covered by programmatic safe harbor agreements, administered by the Sacramento River Forum. In brief, such an arrangement allows private landowners to enter into cooperative agreements with the Sacramento River Forum to allow for more extensive management of elderberry-including, for example, pruning or removing large branches, free from fear of regulatory burdens, fines, or penalties, subject to certain monitoring and reporting provisions. One of these provisions is that the number of elderberry plants on the property should never fall below a baseline number that is established at the time of entry into the agreement. The overall goal of such safe harbor agreements is to provide a net conservation benefit to threatened species by encouraging planting of more elderberry shrubs-a goal accomplished by reducing the regulatory risk to landowners. For more details about entering into a cooperative landowner agreement, please visit the website of the Sacramento River Forum, sacramentoriver.org/forum, or contact the Sacramento River Forum directly (2440 Main St., Red Bluff, CA 96080; 530-518-1011). 


\section{Nutritional compounds of blue elderberry}

Elderberries contain high amounts of bioactive flavonoids, anthocyanins, and phenolic acids. These compounds are associated with the antioxidant activity and some of the beneficial immune responses attributed to elderberry (Thole 2006). Elderberry is also high in vitamin $\mathrm{C}$ and contains vitamins $\mathrm{A}$, B6, and E (Tiralongo 2016). Although more research is needed to establish the effectiveness of elderberry for treatment of various health conditions (Ulbricht et al. 2014), its use in traditional medicine across the globe is well documented (Jaric et al. 2018; Snežana et al. 2007; Walker 2004).

Preliminary data from the UC Davis Department of Food Science and Technology show that blue elderberries grown in the Sacramento Valley have many of the same anthocyanins, flavonoids, and phenolic acids found in the European and American elderberry subspecies. In addition, blue elderberries have comparable or even slightly higher Brix (a measure of flavor or sweetness) than the American and European types. While more research is needed to determine if any flavonoids or anthocyanins are unique to blue elderberry, these initial results are promising indicators that blue elderberry can perform just as well as American and European elderberry-the current market standard-in elderberry-based, health-promoting products. (For more information, visit ucanr. edu/sites/Elderberry).

\section{Market potential for elder harvest}

Elderberry was one of the five best-selling herbs in the United States in 2018. Surveys of California food retailers, herbalists, and specialty food producers in 2019 reflect soaring interest in elderberry products (Smith et al. 2019). ${ }^{1}$ In a 2019 survey of California-based sellers and retailers of elder products, 92 percent of respondents reported that customer demand for elder products was growing, while only 42 percent noted a corresponding increase in supply (Engelskirchen and Brodt 2020). ${ }^{2}$ Many retail establishments carry a large assortment of elder products, representing many different product types-syrups, tinctures, lozenges, capsules, dried loose berriesacross a range of sizes and price points. Most products sold in stores refer on their labels to "black elderberry," with many indicating the use of European elderberry, and just a few indicating the use of American elderberry. Despite there being no observed label recognition for blue elderberries, buyers interviewed showed strong interest in a California-grown supply, especially if supply were consistent and pricing were competitive. Survey results indicated that organic and sustainably grown practices were important to herbalists and home preservers in sourcing elderberry products-whereas, for retailers, consistency of supply and price were more important than organic certification (Engelskirchen and Brodt 2020). By adding elderberry to cropping systems and choosing appropriate sales strategies as detailed below, growers can find an additional revenue stream to enhance farm income and viability.

\section{Making value-added products}

Value-added products such as syrups and jellies made from elderberries and elderflowers can help growers diversify their product offerings and extend sales into the winter months. Specialty markets and regionally focused retailers interviewed in 2019 indicated strong interest in stocking locally made elderberry products-particularly elderberry syrups, the most popular product among consumers. ${ }^{3}$ Products made with berries represented 93 percent of products observed on store shelves, and were far more common than those made with flowers. Among products made from flowers, beverages were the most common product type. On the California Department of Public Health website, growers interested in making value-added products can learn more about California’s Cottage Food Law, cdph.ca.gov/ Programs/CEH/DFDCS/Pages/FDBPrograms/ FoodSafetyProgram/CottageFoodOperations. aspx, and Processed Food Registration, cdph. ca.gov/Programs/CEH/DFDCS/Pages/FDBPrograms/FoodSafetyProgram/ProcessedFoodRegistration.aspx. 


\section{Direct market channels}

Growers seeking sales outlets for fresh, frozen, or dried elderberries or flowers could consider approaching local herbalist schools or guilds, chefs, craft food entrepreneurs, or home food preservers. In surveys, this buyer segment reported using both berries and flowers and expressed interest in fresh, frozen, or dried products, indicating some flexibility around the level of postharvest processing. The majority of those surveyed source elder via various channels-ordering from a wholesaler (64\%), buying directly from a farm (36\%), or foraging on their own (58\%). However, 67 percent said they did not generally find enough supply to meet their needs, and 88 percent said they would "definitely" purchase California-grown elder if it were available.

\section{Wholesale market channels}

In surveys, specialty food entrepreneurs, herb purveyors, and natural food stores expressed interest in purchasing dried elderberries or elderflowers, as well as value-added products. Ninety-three percent of retail businesses interviewed in 2019 believed that their businesses offered a niche for products made with California-grown elder. Only 30 percent said that they already carried products made from California-grown elderberries, pointing to an opportunity for California growers. A large majority of interviewees mentioned syrups as the most popular type of product among their customers, followed by dried berries, gummies, and dried flowers. Growers wishing to do business with buyers such as these should first understand the buyers' requirements concerning volume minimums, supply consistency, food safety, and delivery logistics.

\section{Endnotes}

1. HerbalGram's Market Report (Smith et al. 2019) recorded sales growth for elderberry products of 138 percent in the mainstream channel and 94 percent in the natural channel.

2. Interviews with 14 sellers and retailers of elder products (specialty markets, natural food grocery stores, online herb purveyors, a wellness product brand, and several other food businesses) were conducted in summer and fall of 2019. An additional 2019 survey of 21 retail establishments, in Northern California and online, found many stores carrying a large assortment of elder product types-syrups, tinctures, lozenges, capsules, dried bulk berries - in a range of sizes and price points (Engelskirchen and Brodt 2020).

3. The most common type of product in stores by far was syrup, representing 45 percent of all 182 elderberry product occurrences and 31 percent of all Stock Keeping Units (SKU), followed by gummies at 13 percent ( $11 \%$ of all SKUs), and lozenges at 7 percent ( $9 \%$ of all SKUs).

\section{Acknowledgments}

Figure $1 \mathrm{~A}$ is provided courtesy of the UC Informatics and GIS Statewide Program, utilizing data from Calscape.org.

Figure $1 \mathrm{~B}$ is used with permission of designer Timara Link (Coastal Band, Shmuwich Chumash).

Figure 12 is provided courtesy of the UC Informatics and GIS Statewide Program.

Sidebar 1 figure 1 is provided courtesy of the Lady Bird Johnson Wildflower Center. 


\section{References}

Anderson, M. K. 2005. Tending the wild: Native American knowledge and the management of California's natural resources. Oakland: University of California Press.

Appenteng, M. K., R. Krueger, M. C. Johnson, H. Ingold, R. Bell, A. L. Thomas, and C. M. Greenlief. 2021. Cyanogenic glycoside analysis in American elderberry. Molecules 26(5):1384. https://doi.org/10.3390/molecules26051384

Barret, S. A., and E. W. Gifford. 1933. Miwok material culture: Indian life of the Yosemite region. Yosemite National Park, California: Yosemite Natural History Association.

Barrows, D. P. 1900. The ethno-botany of the Coahuilla Indians of Southern California. Chicago: University of Chicago Press.

Baudry J., R. G. H. Bunce, and F. Burel. 2000. Hedgerows: An international perspective on their origin, function, and management. Journal of Environmental Management 60(1):7-22. https://doi.org/10.1006/ jema.2000.0358

Brodt, S., K. Fyhrie, D. Stewart, and D. A. Sumner. 2020a. Sample costs to establish blue elderberry: High-density hedgerow with tillage, Sacramento Valley. Davis: UC Agricultural and Natural Resources/ UC Agricultural Issues Center/UC Davis Department of Agricultural and Resource Economics. https://coststudyfiles.ucdavis. edu/uploads/cs_public/72/72/7272112b-2dec4cb4-95ed-b4253dd5e981/20blueelderberryhi ghdensityhedgerowwithtillage.pdf

Brodt, S., K. Fyhrie, D. Stewart, and D. A. Sumner. 2020b. Sample costs to establish blue elderberry in a hedgerow without tillage, Sacramento Valley. Davis: UC Agricultural and Natural Resources/UC Agricultural Issues Center/UC Davis Department of Agricultural and Resource Economics. https:// coststudyfiles.ucdavis.edu/uploads/cs_public/ c9/6f/c96fb62f-512f-41bd-b587-7db8d3b437d c/20blueelderberryhedgerowwithouttillage.pdf

Brodt, S., K. Fyhrie, D. Stewart, and D. A. Sumner. 2020c. Sample costs to establish blue elderberry in a multi-species hedgerow with tillage, Sacramento Valley. Davis: UC Agricultural and Natural Resources/ UC Agricultural Issues Center/UC Davis Department of Agricultural and Resource
Economics. https://coststudyfiles.ucdavis.edu/ uploads/cs_public/51/8f/518f9a2f-ebc2-4b728a9c-b551917c18e2/20blueelderberrymultispe cieshedgerowwithtillage.pdf

Byers, P. L., A. L. Thomas, M. M. Cernusca, L. D. Godsey, and M. A. Gold. 2014. Growing and marketing elderberries in Missouri. Columbia: University of Missouri Center for Agroforestry.

Charlebois, D., P. L. Byers, C. E. Finn, and A. L. Thomas. 2010. Elderberry: Botany, horticulture, potential. Horticultural Reviews 37(4):214-280. https://doi. org/10.1002/9780470543672.ch4

(CNPS) California Native Plant Society. 2021a. Blue elderberry. https://calscape. org/Sambucus-nigra-ssp.-caerulea-(BlueElderberry)

(CNPS) California Native Plant Society. 2021b. Calscape California native plant gardening guide: The nature restoration approach. https://calscape.org/planting-guide.php

(CNPS) California Native Plant Society. 2021c. Red elderberry. https://calscape.org/ Sambucus-racemosa-(Red-Elderberry)?srchcr $=\mathrm{sc} 5 \mathrm{dc} 30 \mathrm{cec} 21780$

Dorner, J. 2002. An introduction to using native plants in restoration projects. Plant Conservation Alliance. https://www.fs.fed. us/wildflowers/Native_Plant_Materials/ documents/intronatplant.pdf

Earnshaw, S. 2018. Hedgerows and farmscaping for California agriculture: A resource guide for farmers. 2nd ed. Davis: Community Alliance with Family Farmers. https://www. rcdmonterey.org/images/docs/publications/ CAFF_Hedgerow_Manual_2018.pdf

Emery, D. E. 1988. Seed propagation of native California plants. Santa Barbara: Santa Barbara Botanic Garden.

Engelskirchen, G., and S. Brodt. 2020. Buying blue: Understanding the market and assessing potential for California-grown elderberry. Davis: UC Sustainable Agriculture Research and Education Program. https://ucanr.edu/ sites/Elderberry/files/336248.pdf

Fyhrie, K., S. Brodt, and L. Crothers. 2020. Elderberry field assessment: Sacramento Valley. Davis: UC Sustainable Agriculture Research and Education Program. https:// ucanr.edu/sites/Elderberry/files/331447.pdf 
Golet, G. H., T. Gardali, C. A. Howell, J. Hunt, R. A. Luster, W. Rainey, M. D. Roberts, J. Silveira, H. Swagerty, and N. Williams. 2008. Wildlife response to riparian restoration on the Sacramento River. San Francisco Estuary and Watershed Science 6(2). https://escholarship. org/uc/item/4z17h9qm

Heath, S. K., C. U. Soykan, K. L. Velas, R. Kelsey, and S. M. Kross. 2017. A bustle in the hedgerow: Woody field margins boost on farm avian diversity and abundance in an intensive agricultural landscape. Biological Conservation 212:153-161. https://doi. org/10.1016/j.biocon.2017.05.031

Jarić, S., O. Kostić, Z. Mataruga, D. Pavlović, M. Pavlović, M. Mitrović, and P. Pavlović. 2018. Traditional wound-healing plants used in the Balkan region (Southeast Europe). Journal of Ethnopharmacology 211: 311-328.

Johnson, M. C., A. L. Thomas, and C. M. Greenlief. 2015. Impact of frozen storage on the anthocyanin and polyphenol contents of American elderberry fruit juice. Journal of Agricultural and Food Chemistry 63(23):5653-5659. https://doi.org/10.1021/acs. jafc. 5 b0 01702

Lightfoot, K., and O. Parrish. 2009. California Indians and their environment. Oakland: University of California Press.

Lloyd, M. G., and R. A. Baldwin. 2021. Burrowing rodents: Developing a management plan for organic agriculture in California. Davis: UC Agriculture and Natural Resources Publication 8688. https://doi.org/10.3733/ ucanr. 8688

Long, R., and J. Anderson. 2010. Establishing hedgerows on farms in California. UC Agriculture and Natural Resources Publication 8390. https://doi.org/10.3733/ ucanr. 8390

Maughan, T., B. L. Black, L. A. Rupp, and M. A. Yost. 2018. Propagation techniques for Sambucus cerulea (blue elderberry). Native Plants Journal 19(2):80-88. https://doi. org/10.3368/npj.19.2.80

McDonough, T. C., D. J. Regan, and A. S. Nelson. 2018. Propagation protocol for blue elderberry (Sambucus nigra L. ssp. cerulea (Raf.) Bolli). Native Plants Journal 19(3):254-259. https:// doi.org/10.3368/npj.19.3.254
Morandin, L. A., and C. Kremen. 2013. Hedgerow restoration promotes pollinator populations and exports native bees to adjacent fields. Ecological Applications 23(4):829-839. https://doi.org/10.1890/121051.1

Morandin, L. A., R. F. Long, and C. Kremen. 2014. Hedgerows enhance beneficial insects on adjacent tomato fields in an intensive agricultural landscape. Agriculture, Ecosystems and Environment 189:164-170. https://doi.org/10.1016/j.agee.2014.03.030

Morandin, L. A., R. F. Long, and C. Kremen. 2016. Pest control and pollination costbenefit analysis of hedgerow restoration in a simplified agricultural landscape. Journal of Economic Entomology 109(3):1020-1027. https://doi.org/10.1093/jee/tow086

Senica, M., F. Stampar, R. Veberic, and M. Mikulic-Petkovsek. 2016. Processed elderberry (Sambucus nigra L.) products: A beneficial or harmful food alternative? LWTFood Science and Technology 72:182-188. https://doi.org/10.1016/j.lwt.2016.04.056

Smith, T., M. Gillespie, V. Eckl, J. Knepper, and C. M. Reynolds. 2019. Herbal supplement sales in US increase by $9.4 \%$ in 2018 . HerbalGram 123:62-73. https://www. herbalgram.org/resources/herbalgram/ issues/123/table-of-contents/hg123herbmarketreport/

Smukler, S. M., S. Sánchez-Morenoc, S. J. Fonted, H. Ferris, K. Klonsky, A. T. O’Geen, K. M. Scow, K. L. Steenwerth, and L. E. Jackson. 2010. Biodiversity and multiple ecosystem functions in an organic farmscape. Agriculture, Ecosystems, and Environment 139(1-2):80-97. https://doi.org/10.1016/j. agee.2010.07.004

Snežana, J., Z. Popović, M. MačukanovićJocić, L. Djurdjević, M. Mijatović, B. Karadžić, M. Mitrović, and P. Pavlović. 2007. An ethnobotanical study on the usage of wild medicinal herbs from Kopaonik Mountain (Central Serbia). Journal of Ethnopharmacology 111(1):160-175. https:// doi.org/10.1016/j.jep.2006.11.007

Stevens, M. 2001. Plant guide: Blue elderberry (Sambucus nigra L. ssp. cerulea (L.) R. Bolli). Baton Rouge, Louisiana: National Resources Conservation Service, National Plant Data Center. 
Thole, J., T. Kraft T., L. Sueiro, Y. H. Kang, J. Gills, M. Cuendet, J. Pezzuto, D. Seigler, and M. Lila. 2006. A comparative evaluation of the anticancer properties of European and American elderberry fruits. Journal of Medicinal Food 9(4):498-504. https://doi. org/10.1089/jmf.2006.9.498

Thomas, A. L., P. L. Byers, and M. R. Ellersieck. 2009. Productivity and characteristics of American elderberry in response to various pruning methods. HortScience 44(3):671-677. https://doi.org/10.21273/ HORTSCI.44.3.671

Timbrook, J. 1990. Ethnobotany of Chumash Indians, California, based on collections by John P. Harrington. Economic Botany 44(2): 236-253. http://www.jstor.org/stable/4255231

Tiralongo, E., S. S. Wee, and R. A. Lea. 2016. Elderberry supplementation reduces cold duration and symptoms in air-travellers: A randomized, double-blind placebo-controlled clinical trial. Nutrients 8(4):182. https://doi. org/10.3390/nu8040182

(UC ANR) UC Agriculture and Natural Resources. 2021. Indigenous perspectives on elderberry uses. https:/ucanr.edu/ sites/Elderberry/Indigenous/Indigenous perspectives/

(UC IPM) UC Statewide Integrated Pest Management Program. 2021. How to manage pests in gardens and landscapes: elderberrySambucus spp. family Caprifoliaceae (honeysuckle family). http://ipm.ucanr.edu/ PMG/GARDEN/PLANTS/elderberry.html

Ulbricht, C., E. Basch, L. Cheung, H. Goldberg, P. Hammerness, R. Isaac, K. Khalsa, A. Romm, E. Mills, I. Rychlik, M. Varghese, W. Weissner, R. Windsor, and J. Wortley. 2014. An evidence-based systematic review of elderberry and elderflower (Sambucus nigra) by the Natural Standard Research Collaboration. Journal of Dietary Supplements 11(1):80-120. https://doi. org/19390211.2013.859852.
(UM IPM) University of Missouri Integrated Pest Management. 2017. Understanding herbicide drift issues. https://ipm.missouri. edu/MEG/2017/7/Understanding_Herbicide_ Drift_Issues/

(USDA) United States Department of Agriculture. 2021. Fire effects information system: Index of species information: Sambucus nigra subsp. cerulea. https://www. fs.fed.us/database/feis/plants/shrub/samnigc/ all.html

(USFWS) United States Fish and Wildlife Service. 2017. Framework for assessing impacts to the valley elderberry longhorn beetle (Desmocerus californicus dimorphus). https://www.fws.gov/ sacramento/documents/VELB_Framework. pdf

Walker, M., J. Nunez, M. Walkingstick, and S. A. Banack. 2004. Ethnobotanical investigation of the Acjachemen Clapperstick from blue elderberry, Sambucus mexicana (Caprifoliaceae). Economic Botany 58(1):2124. https://www.jstor.org/stable/4256772

Williams, N. M., K. L. Ward, N. Pope, R. Isaacs, J. Wilson, E. A. May, J. Ellis, J. Daniels, A. Pence, K. Ullmann, and J. Peters. 2015. Native wildflower plantings support wild bee abundance and diversity in agricultural landscapes across the United States. Ecological Applications 25(8): 2119-2131. https://doi. org/10.1890/14-1748.1

Wilson, R., D. Fried, J. Hayden, G. Masé, T. Hardie, J. Faulkner, M. Sisock, T. L. Jackson, D. T. Handley, and M. L. Peronto. 2016. Growing elderberries: A production manual and enterprise viability guide for Vermont and the Northeast. Burlington: University of Vermont Center for Sustainable Agriculture. https://www.uvm.edu/sites/default/files/ media/ElderberryGuideComplete.pdf 


\section{For futher information}

To order or obtain UC ANR publications and other products, visit the UC ANR online catalog at https://anrcatalog.ucanr. edu/ or phone 1-800-994-8849. Direct inquiries to

UC Agriculture and Natural Resources

Publishing

2801 Second Street

Davis, CA 95618

Telephone 1-800-994-8849

E-mail: anrcatalog@ucanr.edu

(C2021 The Regents of the University of California. This work is licensed under the Creative Commons AttributionNonCommercial-NoDerivatives 4.0 International License. To view a copy of this license, visit https://creativecommons.org/ licenses/by-nc-nd/4.0/ or send a letter to Creative Commons, PO Box 1866, Mountain View, CA 94042, USA.

Publication 8709

ISBN-13: 978-1-62711-188-1

The University of California, Division of Agriculture and Natural Resources (UC ANR) prohibits discrimination against or harassment of any person in any of its programs or activities on the basis of race, color, national origin, religion, sex, gender gender expression, gender identity, pregnancy (which includes pregnancy, childbirth, and medical conditions related to pregnancy or childbirth), physical or mental disability, medical condition (cancer-related or genetic characteristics), genetic information (including family medical history), ancestry, marital status, age, sexual orientation, citizenship, status as a protected veteran or service in the uniformed services (as defined by the Uniformed Services Employment and Reemployment Rights Act of 1994 [USERRA]), as well as state military and naval service.
UC ANR policy prohibits retaliation against any employee or person in any of its programs or activities for bringing a complaint of discrimination or harassment. UC ANR policy also prohibits retaliation against a person who assists someone with a complaint of discrimination or harassment, or participates in any manner in an investigation or resolution of a complaint of discrimination or harassment. Retaliation includes threats, intimidation, reprisals, and/or adverse actions related to any of its programs or activities.

UC ANR is an Equal Opportunity/Affirmative Action Employer. All qualified applicants will receive consideration for employment and/or participation in any of its programs or activities without regard to race, color, religion, sex, national origin, disability, age or protected veteran status.

University policy is intended to be consistent with the provisions of applicable State and Federal laws.

Inquiries regarding the University's equal employment opportunity policies may be directed to: Affirmative Action Compliance and Title IX Officer, University of California, Agriculture and Natural Resources, 2801 Second Street, Davis, CA 95618, (530) 750-1343. Email: titleixdiscrimination@ ucanr.edu. Website: https:/ucanr.edu/sites/anrstaff/Diversity/ Affirmative_Action/

To simplify information, trade names of products have been used. No endorsement of named or illustrated products is intended, nor is criticism implied of similar products that are not mentioned or illustrated.

An electronic copy of this publication can be found at the UC ANR catalog website, http://anrcatalog.ucanr.edu/.

UC This publication has been anonymously peer PEER reviewed for technical accuracy by University REVIEWED of California scientists and other qualified professionals. This review process was managed by UC ANR Associate Editor for Agronomy Sciences Sarah Light.

web-9/21-LC/SO 